\title{
Traditional Institutions in Africa, Past and Present
}

\author{
Clara Neupert-Wentz ${ }^{* 1}$ and Carl Müller-Crepon ${ }^{2}$ \\ ${ }^{1}$ Aarhus University \\ ${ }^{2}$ University of Oxford
}

September 2021

Link to most recent version

\begin{abstract}
To what degree and why are traditional institutions persistent? Following up on the literature on the long-term effects of precolonial institutions in Africa, we investigate whether and where today's traditional institutions mirror their precolonial predecessors. We do so by linking new data on contemporary traditional institutions of African ethnic groups with Murdock's historical Ethnographic Atlas. We find a robust association between past and present levels of centralization. However, this persistence originates almost exclusively from former British colonies governed with more reliance on precolonial institutions than other colonies, in particular French ones. These findings contribute to research on the development and effects of traditional institutions, highlighting the need to theoretically and empirically account for variation in the degree of persistence of traditional institutions.
\end{abstract}

Keywords: Institutional development, long-term effects, precolonial institutions, traditional institutions, institutional persistence, colonial legacies, Ethnographic Atlas

\footnotetext{
*Corresponding author.

Clara Neupert-Wentz is an Assistant Professor at the Institute of Political Science, Aarhus University, Denmark. Address: Bartholins Allé 7, 8000 Aarhus C, Denmark. E-mail: clara@ps.au.dk.

Carl Müller-Crepon is a Departmental Lecturer at the Department of Politics and International Relations, Oxford University, United Kingdom. E-mail: carl.muller-crepon@politics.ox.ac.uk.

We thank Pierre Englebert, Ane Foged, Constantin Ruhe, and Julian Schuessler, as well as participants at the APSA Annual Meeting 2019, DPSA 2020, and the AFK Methods workshop 2019 for very helpful comments and feedback.
} 
Institutions connect "the past with the present and the future" (North 1991, 97). The study of institutional development has therefore been central to the social sciences. Yet, the institutional trajectory of traditional political institutions - governing subnational communities based on customary legitimacy - is mostly excluded from the systematic analysis of institutional persistence and change. This is despite wide-ranging evidence of their contemporary importance for economic development, public goods provision, elections, and conflict (e.g., Baldwin 2016; Baldwin and Holzinger 2019; Henn 2020; de Kadt and Larreguy 2018; Logan 2013; Wig and Kromrey 2018).

The lack of research on traditional institutions' change is worrying since a large and growing literature reports robust long-term effects of their precolonial predecessor institutions on development (Michalopoulos and Papaioannou 2013; Gennaioli and Rainer 2007), public goods (Archibong 2019; Wilfahrt 2018), political attitudes (Chlouba, Smith and Wagner 2021), and political violence (Wig 2016; Paine 2019) in Africa. These analyses mostly rely on Murdock's (1967) famous measure of political centralization ("Jurisdictional Hierarchy - v33") of group-level precolonial institutions. The measure counts the number of hierarchical levels of political organization and is a widely-used conceptualization of political complexity in anthropology and archaeology (e.g., Diamond 1997; Currie et al. 2010).

The mechanism often invoked to explain the long-term effects of past institutions on contemporary outcomes is institutional persistence: the view that today's traditional institutions closely mirror their precolonial predecessors. Yet, so far, we lack an empirical test of that assumption of persistence. Without such evidence, institutional persistence is observationally equivalent to persistent effects of precolonial institutions - historical effects of institutions (e.g., leading to past development) that have persisted independent of the institutions themselves. To provide the "missing middle" on the path from past to present (Cirone and Pepinsky 2021, 23), we use new data on contemporary traditional institutions. These allow us to examine whether traditional institutions in Africa have persisted until today or whether they have undergone systematic institutional change, triggered, in particular, by colonial rule.

The extent of such institutional persistence is contested. Consistent with the idea of ubiquitous persistence, Herbst (2000) argues that there has been no significant change of traditional political institutions since the precolonial era. Correspondingly, De Juan (2017) finds cultural centers of the precolonial Burundi kingdom to persist as customary courts today. Concerned with cultural persistence, Bahrami-Rad, Becker and Henrich (2021) find that Murdock's (1967) precolonial measures of kinship organization, social norms, and customs significantly correlate with survey-based counterparts from today. A similar finding - that Murdock's polygyny measure corresponds to high levels of polygyny in ethnic groups today - has been documented by 
Dalton and Leung (2014).

Yet, political institutions also reflect and determine the distribution of political power (Acemoglu, Egorov and Sonin 2021) and may thus change when power shifts. From this perspective, many argue that political engineering, attempts to abolish traditional institutions, and the invention of institutions resulted in an institutional present of traditional authority that differs substantively from its precolonial past (Young 1994; Englebert 2002; Ranger 1983). In particular, European colonial rule on the African continent is argued to have systematically changed traditional institutions. Variation in colonial styles can, therefore, be seen as an important cause of variation in the survival of precolonial institutions. It is thus suggested that French direct rule destroyed traditional institutions while British indirect rule integrated traditional institutions into the colonial state, thereby fostering their persistence (Ali et al. 2018; Crowder 1968; Müller-Crepon 2020).

We seek to address this debate empirically and ask: Do contemporary traditional institutions reflect their precolonial predecessors or have they been systematically changed by colonial styles of direct and indirect rule? While Baldwin and Holzinger $(2019,1748)$ acknowledge that today's traditional institutions are not "accurate reflections of historic governance practices," we so far lack a systematic and continent-wide examination of the link between historical and contemporary traditional institutions.

This is in particular due to a lack of data. Existing continent-wide datasets on traditional authorities are survey-based and provide only information on individual perceptions and trust, rather than their institutional structure. Some studies systematize knowledge on contemporary traditional institutions but are limited to single countries. Such data includes, for example, the number of ruling families within chiefdoms in Sierra Leone (Acemoglu, Reed and Robinson 2014), formal contests of traditional leadership in South African municipalities (Mustasilta 2021), or qualitative comparisons of traditional governance systems across selected ethnic groups in Namibia, Kenya, Tanzania, and Uganda (Holzinger, Kern and Kromrey 2017). On a continental scale, Kromrey (2021) compiles information on traditional political systems and democratic attributes across a select group of 142 politically relevant ethnic groups (see also Cederman, Wimmer and Min 2010)(see also Neupert-Wentz, Kromrey and Bayer 2021), a selection criterion which may itself be an outcome of institutional persistence.

To address the need for complete comparative data, we use new expert-coded data on 566 African ethnic groups' contemporary traditional institutions that are similar to yet more detailed than Murdock's (1967) measure of precolonial centralization (“Jurisdictional Hierarchy - v33"). ${ }^{1}$

\footnotetext{
${ }^{1}$ These data are from the Reinhart Koselleck Project "Traditional Governance and Modern Statehood" carried out at the University of Konstanz, Germany (German Research Foundation (DFG) grant HO 1811/10-1 PI: Katharina Holzinger). We acknowledge support in data collection by Katharina Holzinger, Axel Bayer, Daniela Behr, Roos Haer,
} 
We rely on a battery of characteristics of contemporary institutions that together measure their political complexity. This includes indicators on traditional leaders, the existence of institutions such as houses of elders and customary courts, their level of organization, institutional functions, as well as their ties to the formal state.

Our analysis shows a robust relationship between past and present levels of institutional centralization. However, this general persistence is primarily driven by ethnic groups in former British colonies where indirect rule was applied in particular to centralized groups. More direct rule by the French led to a substantively and statistically insignificant relationship between past and present levels of traditional authorities' institutionalization. Suggesting a continuation of patterns of colonial indirect rule through the post-colonial period, we find that countries that formerly experienced indirect rule are more likely to have integrated traditional institutions into their constitutions today.

\section{Traditional Institutions in Africa: Persistence and Change}

The literature on long-term effects of precolonial institutions typically attributes the assumed institutional persistence to path-dependence, a "historical causality" rooted in the institution itself (see Page 2006, 87). The initial institution sets out the path, which can result in persistence with no institutional changes over time or gradual path-dependent changes, endogenous to the institution (e.g., Mahoney and Thelen 2009; Acemoglu, Egorov and Sonin 2021; Gerschewski 2020). No change in the institution - "stasis" - is the predominant form of persistence that is assumed in the social sciences (Acemoglu, Egorov and Sonin 2021,367).

While stasis and gradual institutional build-up can occur conditionally on the path, institutional destruction is often non-gradual. Analyzing the political evolution of Austronesianspeaking societies, Currie et al. (2010) show that increases in political complexity - e.g., from an acephalous society to a chiefdom with one administrative level - occur incrementally. However, political breakdown from complex societies to less complex societies can be abrupt, with centralized states breaking apart into acephalous societies.

Institutional change, and in particular destruction, can be induced by causes external to the institution (e.g., Gerschewski 2020). Mainga (2010 [1973]) describes, for instance, the precolonial political development of the Lozi Kingdom as a gradual development from a more loosely organized confederation to a highly centralized kingdom. The Lozi state fell in the middle of the $19^{\text {th }}$ century due to an outside invasion of the Makololo. ${ }^{2}$ After sixteen years, the Lozi regained their

\footnotetext{
Fabian Bergmann, and Sven-Patrick Schmid.

${ }^{2}$ Mainga argues that the invasion was partially successful as it was paired with internal frictions and weaknesses of the kingdom, such as unclear succession rules (Mainga 2010 [1973], 63).
} 
sovereignty (Mainga 2010 [1973], 61) but shortly after faced the arrival of European colonizers.

Assuming stasis, hence, may mask historical and contextual variation. Powerful external actors that want to govern and subject existing institutions decrease the likelihood of persistence by altering, alienating, or destroying them. As institutions both reflect and determine political power, we have to consider systematic alterations of the distribution of political power as most likely moments of rapid institutional change.

European colonial rule constituted the most rampant and continent-wide external shock to indigenous institutions. The Scramble for Africa - reaching its violent climax after the Berlin conference in 1884/1885 - established European rule across the African continent hitherto governed by indigenous institutions. While all colonizers relied on traditional institutions at the very local level (Herbst 2000; Mamdani 1996), the directness of rule at higher administrative levels varied between colonizers, in particular between the French and British empires which ruled over most of the African continent and population (Asiwaju 1970; Crowder 1968; Miles 1994).

Specifically, historical evidence suggests that the French ruled more directly than the British. Following a "Republican spirit," (Cohen 1971) the French met precolonial political institutions with hostility (Huillery 2010). French colonialists stripped old local elites of most of their power and transferred it to "commandants de cercle," administrators who rotated too often to acculturate themselves locally (e.g., Cohen 1971; Conklin 1997; Crowder 1968). British colonial rulers, conversely, are oftentimes described as co-opting precolonial institutions and elites to indirectly rule through them (Crowder 1968). As a result, Müller-Crepon (2020) has recently shown that among 124 African precolonial states $70 \%$ of the ruling lines of succession persisted until independence under British rule, while only $30 \%$ did so under French rule. If the French hostility towards precolonial states permanently destroyed some of the centralized institutions they had conquered while British rule fostered their persistence, we would expect less institutional persistence in French than in British colonies.

The Lozi are an example of this, on whose institutions British colonizers ${ }^{3}$ left a comparatively light mark by giving some autonomy to the Lozi's Barotseland (Mainga 2010 [1973], 190; Zeller and Melber 2019, 299). By 1924 Barotseland became "a protectorate within a protectorate" of the British Empire (Zeller and Melber 2019, 302) and in 1936, the Barotse Native Authority was established, which governed the territory with "far-reaching responsibilities in the fields of land and natural resource management, jurisdiction, and law enforcement" (Zeller and Melber 2019, 302). While the Lozi political system certainly did not remain untouched by British colonial rule, the Lozi could preserve their institutions more than many other traditional political systems

\footnotetext{
${ }^{3}$ Lozi territory was partitioned between British, German, and Portuguese colonizers, but its mainland fell under British control (Mainga 2010 [1973], 162; Zeller and Melber 2019, 293).
} 
(Ranger 1968, 228) and direct British administration was limited only to "regions which had never been more than loosely under Lozi control" (Mainga 2010 [1973], 190).

After independence, the Lozi were first given autonomy within the newly independent Zambian state through the Barotseland Agreement of 1964. Yet, these rights were soon dismantled by the government, which - in contrast to British colonizers - "sought to relocate and isolate Lozi authorities from the realm of everyday administration into a sphere of depoliticized 'folklore."'(Zeller and Melber 2019, 306). Such attempts to overrule and replace the Lozi Kingdom were unsuccessful - also due to the absence of a capable centralized Zambian state (Zeller and Melber 2019; Herbst 2000) - and led to continued demands for self-determination from the Zambian state.

As implied by the Lozi case, we note that indirect rule was not applied uniformly across the British colonies, which further underpins the need for our comparative analysis. The British integrated centralized and hierarchical precolonial institutions, e.g., the Lozi Kingdom (Mainga 2010 [1973]), the Fulani Emirates (Miles 1994) or the Buganda Kingdom (Reid 2002), into the colonial state by co-opting their leaders who retained much of their accustomed powers. However, where societies lacked centralized institutions the creation of new institutions was imperative for the roll-out of colonial rule (e.g. Fortes and Evans-Pritchard 1940; Hicks 1961). This led to a more direct style of colonial rule (Gerring et al. 2011; Müller-Crepon 2020). Some of the newly created local institutions were headed by (invented) local elites such as the "Warrant Chiefs" in previously acephalous southeastern Nigeria (Afigbo 1972). To the degree that these embedded themselves locally, we would expect some limited centralization of previously decentralized ethnic groups, leading to institutional change. Given that all colonizers relied on local indigenous elites (Herbst 2000; Mamdani 1996), such institutional "upgrading" in decentralized areas was not a phenomenon limited to British colonies.

For the difference between the French and British styles of colonial rule to consistently affect traditional institutions until today, postcolonial governance arrangements between the state and traditional authorities must roughly correlate with colonial ones. Otherwise, postcolonial change of traditional institutions could have slowly washed out the effects of colonial rule. Our results will shed brief light on this mechanism.

\section{Data and Research Design}

To analyze whether precolonial ethnic institutions persist, we combine two datasets that provide information on ethnic institutions in the precolonial past and the present. The first is Murdock's (Murdock 1959, 1967) Ethnographic Atlas $(E A)$ that contains information on ethnic groups' po- 
litical institutions around the time of colonization. Second, the Traditional Governance Groups Dataset (TGG, Baldwin and Holzinger 2019) is derived from an online survey of 1122 experts who provided detailed information on traditional institutions across the African continent today.

Murdock's Ethnographic Atlas: The EA is a dataset that compiles information on social, political, and cultural traits of around 1200 ethnic groups worldwide around or before European colonization. It was coded by anthropologist Murdock, who relied on in-depth ethnographic work from secondary sources. Murdock claims to have surveyed "[p]ractically the entire ethnographic literature" $(1967,1)$ available at the time and used (translated) material in all languages to avoid selection biases. Murdock argues that - at the time of coding the data - the ethnographic literature on the African continent was, by comparison, the most complete $(1967,7)$.

Throughout the 1960s, Murdock published the EA in 21 installments in the journal Ethnology and the corresponding book was published in 1967. Despite critique and general scepticism towards the comparative exercise from within the anthropological discipline (see Bahrami-Rad, Becker and Henrich 2021, 1; see also, e.g., Tobin 1990; Boas 1896), the data recorded in the EA has lately become an important source for quantitative analyses in the social sciences. Bahrami-Rad, Becker and Henrich (2021, Appendix pp.1-2) list 64 recent peer-reviewed articles that use the $E A$, of which 17 use Murdock's centralization variable, on which we focus in this article.

EA's variable no. 33 - "Jurisdictional Hierarchy Beyond Local Community (v33)" - is an ordinal measure of ethnic groups' political complexity that counts a society's institutional levels (Murdock 1967, 52). It is one of two variables of the EA that captures political institutions. ${ }^{4}$ It is zero where there exists no political authority beyond the local community. Groups with one level beyond the local community are called "petty chiefdoms," followed by "large chiefdoms," as well as "states," and finally "large states" on level four. Centralized states have the highest level of political complexity and are "characterized by a centralized political bureaucracy that contains a number of more specialized administrative offices" (Currie et al. 2010, 801). In the case of the precolonial Lozi Kingdom in today's Zambia, such centralization included "a hierarchy of 'officers of state' and 'a general Council' comprising 'state officials', chiefs and subordinate governors" (Mainga 2010 [1973], 38) and was required for an array of economic functions and to organize labor such as "[m]ound building and canal construction for drainage and transportations" (Mainga 2010 [1973], 32)

Without affecting the results substantively, we reduce the influence of the outlying four large states by recoding them to states (3). Our measure of precolonial centralization (v33) therefore ranges from 0 to 3. The EA was geocoded by Nunn and Wantchekon (2011) using Murdock's

\footnotetext{
${ }^{4}$ The other measure is variable no. 72 "succession to the office of local headman."
} 
(1959) map of African ethnic 'homelands,' our unit of analysis. Because many of Murdock's 841 groups' settlement areas span across several countries, we split them into 1321 groups nested within today's country borders.

Traditional Governance Groups Data: We measure contemporary traditional institutions with new data collected via a global online expert survey on ethnic groups' traditional institutions, their leaders and functions. The survey was in the field from 2016 to 2017 and contacted over 7000 experts for ethnic groups around the world. Similar to the $E A$, experts were mostly ethnologists and anthropologists and were surveyed in English, French, Spanish, Portuguese, and Russian to prevent selection bias. The resulting dataset combines information from 1122 experts for 746 African groups (1.5 experts per group). Data on groups with multiple expert answers generally show high levels of agreement and were aggregated manually to incorporate additional comments provided by the surveyed experts. Appendix A.1 further describes the data collection and aggregation, and reports inter-coder agreement.

The universe of groups for the expert survey is mainly based on the All Minorities at Risk (AMAR) list of socially relevant ethnic groups (Birnir et al. 2014). Social relevance denotes that "people notice and condition their actions on ethnic distinctions in everyday life" (Fearon 2006, 852). Thereby, the population of the contemporary data on traditional institutions is not affected by any form of institutional or political organization, which could result in post-treatment bias by selecting specific important groups on the outcome variable. Furthermore, the population is sufficiently fine-grained to be matched with Murdock's groups.

Ethnic Matching: To link the TGG to Murdock's EA in a coherent and replicable manner, we draw on the Linking Ethnic Groups in Africa project by Müller-Crepon, Pengl and Bormann (2020) who leverage the universe of known languages and dialects to link datasets on ethnic groups in Africa. Matching groups from the two datasets if they share a language or dialect, we match 579 (84.3\%) groups from the TGG data to a total of 731 (55.3\%) groups enumerated by Murdock. As we demonstrate in an analysis of the determinants of finding a match in Appendix A.3, many unmatched groups in the EA are small group segments that spill across international borders.

An important concern with this intertemporal matching is the introduction of selection bias. If groups whose traditional institutions were destroyed at some point since colonization are less likely to be enumerated in TGG, we would underestimate the amount of change. We therefore conduct a descriptive analysis of the attributes of EA groups that lack a link to TGG (Appendix A.3). In general, we find no systematic effect of precolonial centralization but larger and more populous groups are more often present in the TGG data. However, we do find that centralized groups in former French colonies are less likely to appear in the TradGov data than centralized 
groups in former British colonies. Appendix C.4 therefore analyses the resulting potential for selection bias and finds our main results to be robust.

Main outcomes: To assess the political complexity of traditional political institutions (TPI) today, we focus on variables from the TGG data that capture institutions, leaders, functions, and ties between states and customary authorities.

\section{Institutions:}

TPI Level: Coding of experts of the highest level of traditional organization, indicating whether a group is acephalous, organized on the district or regional level, or a higher level. This is the variable that coincides most with Murdock's ordinal coding of precolonial centralization (v33).

Institution Index: This is the mean of a series of dummy variables that encode whether an ethnic group features a council of elders and/or the king, assemblies, dispute resolution mechanisms such as courts, and native customary rules.

\section{Leaders:}

Leader Index: The average existence of a series of leadership roles, ranging from a king or paramount chief, over chiefs, headmen, judges, healers, to spiritual leaders.

Max Leader: Again oriented towards Murdock's level of centralization, we encode the maximum hierarchical level on which a leader exist with kings being on level 3, chiefs on level 2 , and headmen on level 1. Groups that have none of these political leaders are coded as 0.

\section{Ties with the state:}

The State-ties Index is the average response to the question of whether traditional authorities are (1) formally acknowledged by the state, (2) interact regularly through formal institutions, and on (3) the strength of traditional authorities' informal ties to state politicians.

\section{Functions:}

The Functions Index is the average existence of official or unofficial responsibility of a groups' traditional institutions for the governance of land, culture, family matters, dispute resolution, health, security, religion, and infrastructure.

These variables together reflect the differentiation and complexity of ethnic groups' traditional political organization. Such complexity can be affected by, for instance, the layers of hierarchy and centralization, a diverse set of distinct political functions, including land administration and security, as well as differentiated and specialized institutions, such as customary judicial courts and councils of elders. 
In order to derive a single measure of the political complexity of traditionally governed groups that minimizes information loss, we extract the first principal component from the data. Our institutional dimensions are all strongly and positively correlated with this first principal component, which explains $50.7 \%$ of their variance (see Appendix A.2). This component, named TPI Index hereafter, is a measure of the political complexity of the group and constitutes the main outcome of the empirical analyses. We also present results for the constitutive parts of the index to investigate differential levels of persistence across the dimensions of traditional institutions (below and in Appendix C.1).

Model specification: We assess the relationship between ethnic groups' precolonial centralization and the index of today's traditional institutions (1) among all observations and (2) contrasting groups from former British and French colonies ${ }^{5}$ using linear models:

$$
\begin{aligned}
& \text { TPI Index } i=\alpha_{c}+\beta_{1}{\mathrm{v} 33_{\mathrm{i}}}+\boldsymbol{\delta} \boldsymbol{X}_{\boldsymbol{i}}+\epsilon_{\mathrm{i}}, \\
& \text { TPI Index } i=\alpha_{c}+\beta_{1} \text { British }+\beta_{2} \text { British } * v 3{ }_{i}+\beta_{3} \text { French } * v 3_{i}+\delta \boldsymbol{X}_{\boldsymbol{i}}+\epsilon_{\mathrm{i}} \text {, }
\end{aligned}
$$

where country-fixed effects $\alpha_{i}$ net the data of all variation among ethnic groups $i$ that is constant within (contemporary) countries. ${ }^{6}$ In the baseline specification (1), the level of historical persistence is captured by the coefficient $\beta_{1}$. In Equation (2), $\beta_{2}$ and $\beta_{3}$ capture the level of institutional continuity in former British and French colonies, respectively. We cluster standard errors on the level of ethnic groups (based on Murdock's coding), many straddling across international borders.

We add a vector of control variables $\boldsymbol{X}_{i}$ to account for 'pre-treatment' factors that may have simultaneously caused past and current institutions. ${ }^{7}$ We sequentially add three vectors of controls to our model: Baseline controls include groups' population, area, distance to coast, and navigable river since large groups and those connected to larger economic markets via waterways may have had a stronger tendency towards centralization. Building on research on the natural fundamentals of political centralization (e.g. Herbst 2000), nature controls include median altitude and slope, mean annual temperature, precipitation and evapotranspiration, the ratio of the two, agricultural suitability, and soils' suitability for cash crop production. Ethnic controls are the reliance on agriculture and pastoralism, as well as the intensity of agricultural activities capturing the potential economic roots of institutional centralization. See Appendix A.4 for details.

\footnotetext{
${ }^{5}$ Note that the former Belgian and Portuguese colonies in Africa lack statistical power for reliable estimates.

${ }^{6}$ See Appendix C.2 for roughly equivalent results without country-fixed effects.

${ }^{7}$ Appendix C.3 presents models with interactions of $\boldsymbol{X}_{\boldsymbol{i}}$ with the French/British dummy. The point estimates of interest remain stable but standard errors increase due to reduced statistical power.
} 


\section{Results: Traditional Institutions, Past and Present}

We start our analysis by visualizing the bivariate relationship between past and present African traditional political institutions in Figure 1. Focusing first on the full sample to the left, we see a consistent and positive relation between Murdock's measure of political centralization (v33) and our TPI Index, suggesting institutional persistence. However, the correlation is far from perfect and disturbed by many 'off-diagonal' cases of institutional change. Splitting the sample between ethnic groups in former British $\left(N_{\text {British }}=289\right)$ and French $\left(N_{\text {French }}=166\right)$ colonies highlights the type of colonial rule as an important source of change. Traditional institutions are highly persistent in former British colonies, which were often ruled through rather than against precolonial institutions. In contrast, institutional change is rampant under French rule, where precolonially centralized groups are not, on average, more institutionalized today than precolonially decentralized ones.

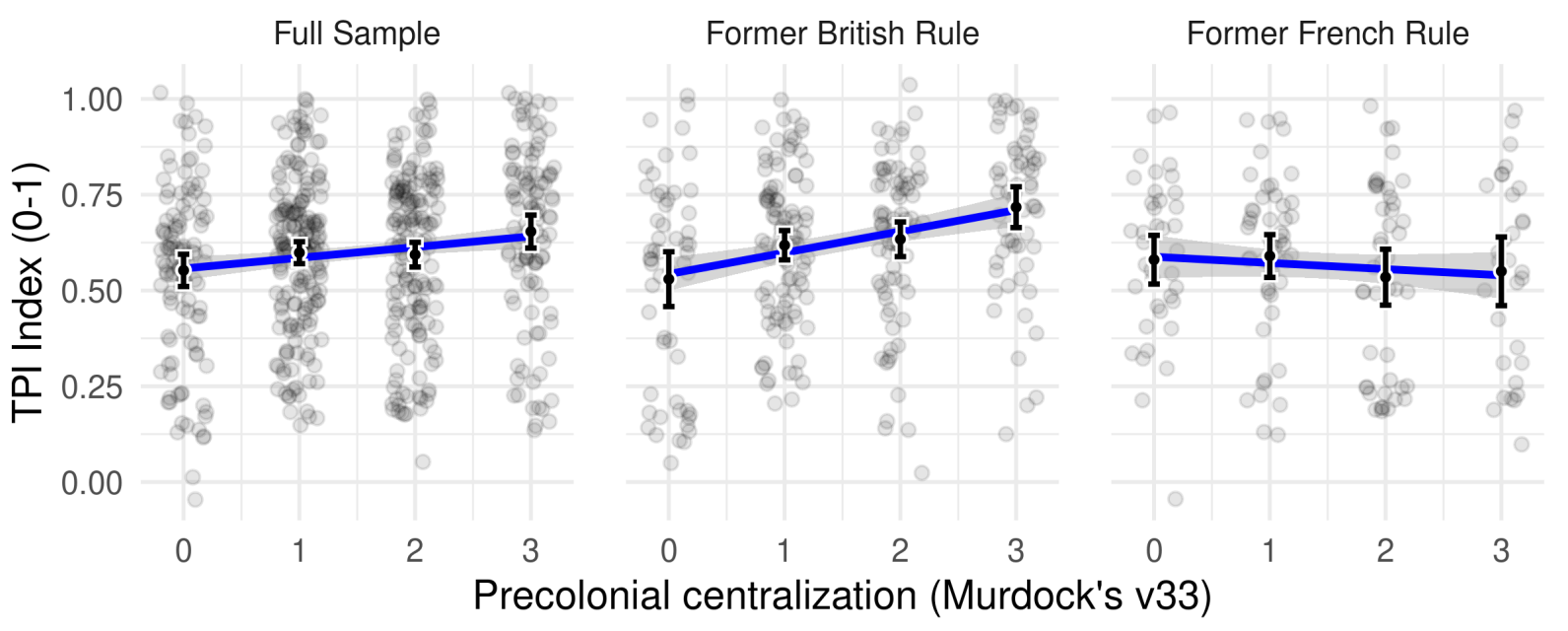

Figure 1: Correlation of precolonial centralization with the TPI Index across all observations and groups in former British and French colonies.

Estimating variations of Eq. (1) in which we sequentially add the various control variables, the first block of coefficients of precolonial centralization in Figure 2 shows a robust positive relationship with the TPI Index across colonies (see also Table A5 in Appendix B). As we add our control variables in specifications 2 to 4 , the size of the coefficient of precolonial centralization decreases only slightly and its precision remains high. An increase of precolonial centralization by one level leads to an increase of a fifth of a standard deviation of the TPI Index.

The remaining blocks of Figure 2 show the relation to the single variables that are used to create the TPI Index. Across outcomes, precolonial centralization has a positive and significant effect on these components. Worth noting are the outcomes TPI Level and the Institutions Index, where precolonial centralization has the biggest effect. TPI Level records the highest level of 
traditional organization, indicating whether a group is acephalous, organized on the district, regional, or higher level. It is therefore most similar to Murdock's political centralization measure. The Institutions Index captures the average institutionalization of a group, with higher numbers indicating more institutions, including councils, assemblies, and courts. The state-ties index is the only outcome that is not significantly related to precolonial centralization across all specifications.

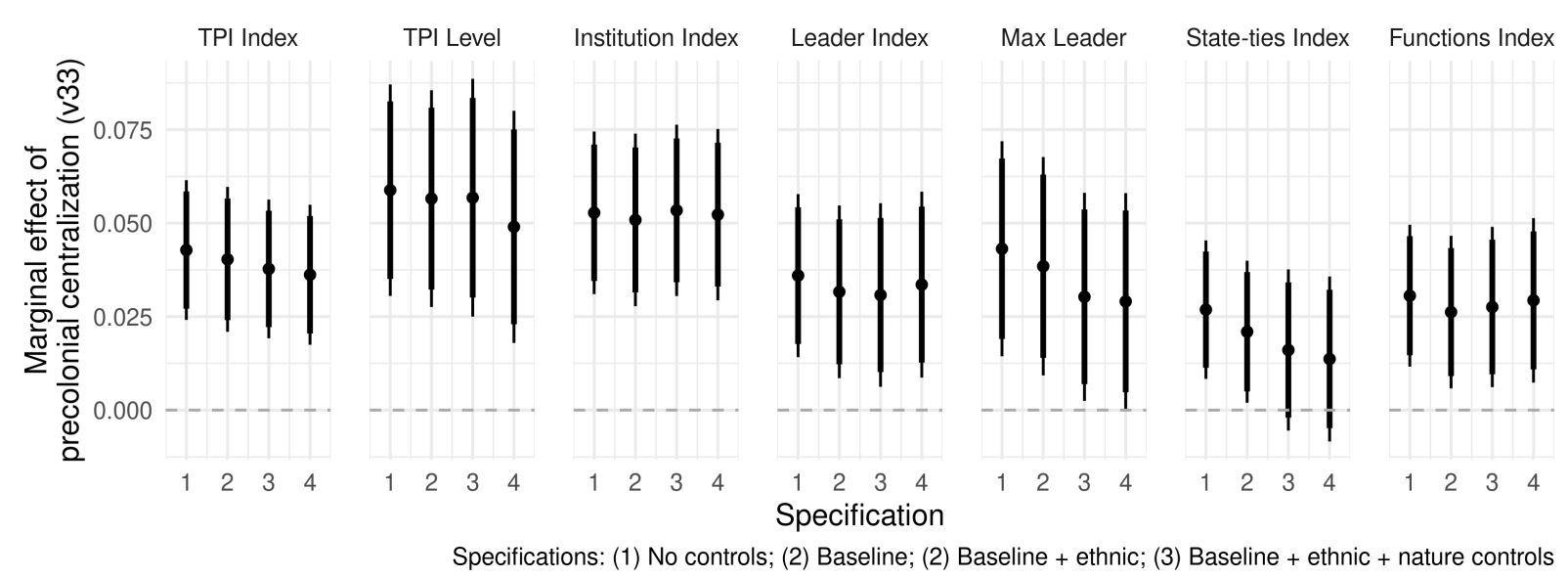

Figure 2: Effect of precolonial centralization (Murdock's v33) on TPI Index and its components across specifications with $95 \%$ and $90 \%$ CIs. See Appendix B for details.

Figure 3 formally tests whether British rule led to the persistence of precolonial institutions while French direct rule crushed precolonially centralized institutions (Eq. (2)). The first block of coefficients reiterates the estimated overall effect of precolonial centralization on today's TPI Index across our four specifications (see also Figure 2). The second and third blocks plot the respective results for the British and French sub-samples, respectively. The fourth block finally shows the French-British difference between the estimated effect of precolonial centralization on the TPI Index. ${ }^{8}$

The results show that the overall correlation between precolonial centralization and our TPI Index is almost exclusively driven by ethnic groups in former British, rather than French colonies. The respective coefficient ( $\mathrm{v} 33 \times$ British) in the second block is slightly larger than estimated on the full sample and statistically highly significant. In turn, the estimated relation between past centralization and the TPI Index in former French colonies is close to zero. The difference between the two estimates in the fourth block turns statistically insignificant once we add the full vector of control variables but remains stable in size.

We disaggregate the analysis of French-British differences in institutional persistence using the constitutive parts of the TPI Index in Appendix C.1. We find the most pronounced differences

\footnotetext{
${ }^{8}$ The results are also contained in Table A6 in Appendix B.
} 


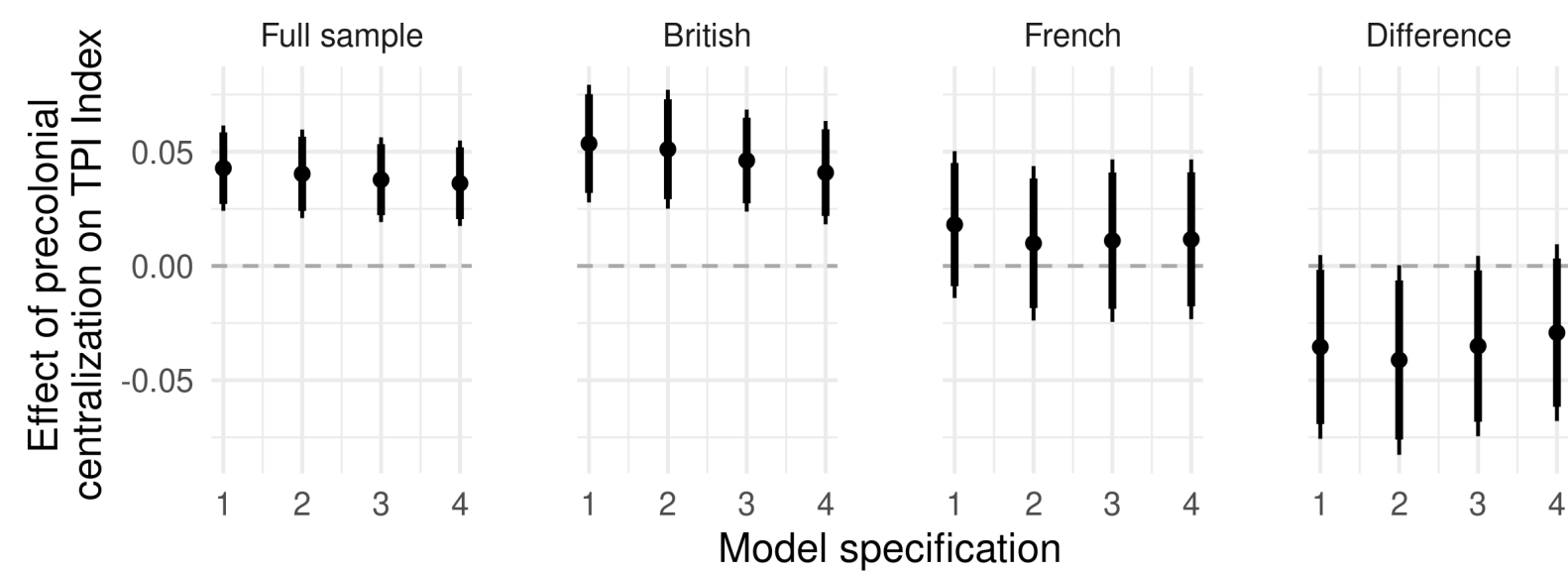

Specifications: (1) No controls; (2) Baseline; (2) Baseline + ethnic; (3) Baseline + ethnic + nature controls

Figure 3: Estimated effect of precolonial centralization on TPI Index across specifications with $95 \%$ and $90 \%$ CIs. See Appendix B for details.

in the number of traditional institutions, their ties to the state, as well as their functions. These are much stronger and positively correlated with precolonial centralization in former British than in former French colonies where a relationship is absent. In turn, differences in the TPI Level and the presence of certain leaders are substantively less pronounced and statistically insignificant. These results suggest that the type of colonial rule did not only affect the level of institutionalization of traditional authorities but importantly also their relation to the formal state and their functions in local governance until today.

This difference is underlined by our final analysis (Appendix D) which sheds light on an important driver of the post-colonial persistence of the setup of traditional institutions. As many independent states built their constitutions upon the metropolitan blueprints they inherited from their colonizers, the degree to which constitutions accommodate and grant powers to traditional authorities or not may explain part of the persistence in former British colonies and its absence in former French ones. Using data on the constitutionalization of traditional authorities for former French and British colonies in 2014 from Holzinger et al. (2019), we find that constitutions in former British colonies acknowledge, regulate, and integrate traditional authorities to a substantively greater degree than those in former French colonies. This suggests that the post-colonial continuation of indirect arrangements of rule play at least some role in the persistence of pre-colonial institutions in former British colonies.

In sum, our results suggest that precolonial institutions are, on average, persistent. Yet, we also find strong institutional legacies of indirect colonial rule, used by the British mostly to rule over politically centralized regions. Under British rule, these institutions could persist while they were dismantled under French rule, resulting in a break between past and present 
institutions.

\section{Conclusion}

In an effort to "decompress history" (Austin 2008), this article has assessed the degree to which precolonial institutions in Africa have persisted over the past century. Our analysis is motivated by a large and growing literature on the enduring effects of precolonial institutions, many of which are implicitly or explicitly assumed to be due to institutions' persistence over time. To assess the empirical merits of this assumption, we have combined data on the precolonial centralization of ethnic groups with expert-coded information on their contemporary traditional institutions.

Our empirical analysis shows a robust association between past and present degrees of political complexity of traditional authorities. This suggests that traditional institutions have been, on average, persistent over the past century. However, and consistent with arguments about the effects of direct and indirect rule on precolonial institutions, this result is almost exclusively driven by ethnic groups in former British colonies where indirect rule and its postcolonial constitutional legacies preserved local institutions.

While it is not possible to judge the counterfactual institutional development in the absence of colonialism, the persistence we find for groups in former British colonies may indicate that an approach that did not treat local institutions with the same hostility as the French one contributed to their persistence. In that way, one can imagine that in the absence of colonialism, continent-wide persistence would have been much stronger.

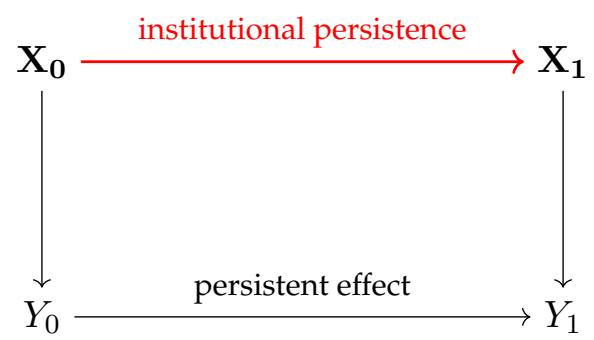

Figure 4: Graph of different paths of long term effects

Note: $X_{0}$ are precolonial institutions, $X_{1}$ are contemporary traditional institutions. $Y_{0}$ is a precolonial outcome, such as development, and $Y_{1}$ is its contemporary equivalent. Effects of $X_{0}$ on $Y_{1}$ driven by institutional persistence run through contemporary institutions $X_{1}$. Persistent effects of past institutions run through mediator $Y_{0}$, e.g., past development. If only precolonial institutions $X_{0}$ and the outcome $Y_{1}$ are measured, it is impossible to distinguish the different paths via $X_{1}$ or $Y_{0}$.

Our findings suggest additionally that future studies on the long-term effects of precolonial institutions on various contemporary outcomes (i.e., interested in the effect of $X_{0}$ on $Y_{1}$ as shown in Figure 4) should differentiate between two broader mechanisms. First, institutional 
persistence ( $X_{0}$ affecting $Y_{1}$ through $X_{1}$ ), which is largely limited to former British colonies. Second, persistent effects of past institutions - a historical effect of institutions that has persisted independent of the institutions themselves ( $X_{0}$ affecting $Y_{1}$ through $\left.Y_{0}\right)$ - are possibly geographically unlimited. These two mechanisms have previously been largely undifferentiated due to the lack of data measuring traditional institutions today.

Finally, we have only considered colonial state-level drivers of institutional change and their postcolonial legacies. Theorizing and analyzing postcolonial change may constitute a promising avenue to foster our understanding of the present of traditional institutions in Africa. 


\section{References}

Acemoglu, Daron, Georgy Egorov and Konstantin Sonin. 2021. Institutional change and institutional persistence. In The Handbook of Historical Economics. Elsevier pp. 365-389.

Acemoglu, Daron, Tristan Reed and James A. Robinson. 2014. “Chiefs: Economic Development and Elite Control of Civil Society in Sierra Leone." Journal of Political Economy 122(2):319-368. URL: $h$ ttps://doi.org/10.1086/674988

Afigbo, Adiele Eberechukwu. 1972. The Warrant Chiefs: Indirect Rule in Southeastern Nigeria 18911929. Longman.

Ali, Merima, Odd-Helge Fjeldstad, Boqian Jiang and Abdulaziz Shifa. 2018. “Colonial Legacy, State-building and the Salience of Ethnicity in Sub-saharan Africa." The Economic Journal .

Archibong, Belinda. 2019. "Explaining divergence in the long-term effects of precolonial centralization on access to public infrastructure services in Nigeria." World Development 121:123-140.

Asiwaju, Anthony I. 1970. The Aleketu of Ketu and the Onimek of Meko: The Changing Status of two Yoruba Rulers under French and British rule. In West African Chiefs. Their Changing Status under Colonial Rule and Independence, ed. Michael Crowder and Obaro Ikime. University of Ife Press pp. 134-161.

Austin, Gareth. 2008. "The "reversal of fortune" thesis and the compression of history: Perspectives from African and comparative economic history." Journal of International Development 20:996-1027.

Bahrami-Rad, Duman, Anke Becker and Joseph Henrich. 2021. "Tabulated nonsense? Testing the validity of the Ethnographic Atlas." Economics Letters .

Baldwin, Kate. 2016. The Paradox of Traditional Chiefs in Democratic Africa. Cambridge University Press.

Baldwin, Kate and Katharina Holzinger. 2019. "Traditional political institutions and democracy: reassessing their compatibility and accountability." Comparative Political Studies 52(12):17471774.

Birnir, Jóhanna K, Jonathan Wilkenfeld, James D Fearon, David D Laitin, Ted Robert Gurr, Dawn Brancati, Stephen M Saideman, Amy Pate and Agatha S Hultquist. 2014. "Socially Relevant Ethnic Groups, Ethnic Structure, and AMAR." Journal of Peace Research 52(1):110-115.

Boas, Franz. 1896. "The limitations of the comparative method of anthropology." Science 4(103):901-908.

Cederman, Lars-Erik, Andreas Wimmer and Brian Min. 2010. “Why do ethnic groups rebel: new data and analysis." World Pol. 62:87. 
Chlouba, Vladimir, Daniel S Smith and Seamus Wagner. 2021. “Early Statehood and Support for Autocratic Rule in Africa." Comparative Political Studies p. 00104140211036031.

Cirone, Alexandra E and Thomas B Pepinsky. 2021. "Historical Persistence." Available at SSRN . URL: $h t t p: / / d x$.doi.org/10.2139/ssrn.3873011

Cohen, William B. 1971. Rulers of Empire: the French Colonial Service in Africa. Hoover Institution Press.

Conklin, Alice L. 1997. A Mission to Civilize. The Republican Idea of Empire in France and West Africa, 1895-1930. Stanford University Press.

Crowder, Michael. 1968. West Africa under Colonial Rule. Hutchinson.

Currie, Thomas E, Simon J Greenhill, Russell D Gray, Toshikazu Hasegawa and Ruth Mace. 2010. "Rise and fall of political complexity in island South-East Asia and the Pacific." Nature 467(7317):801-804.

Dalton, John T and Tin Cheuk Leung. 2014. "Why is Polygyny More Prevalent in Western Africa? An African Slave Trade Perspective." Economic Development and Cultural Change 62(4):599-632.

De Juan, Alexander. 2017. "“Traditional” resolution of land conflicts: The survival of precolonial dispute settlement in Burundi." Comparative Political Studies 50(13):1835-1868.

de Kadt, Daniel and Horacio A Larreguy. 2018. "Agents of the regime? Traditional leaders and electoral politics in South Africa." The Journal of Politics 80(2):382-399.

Diamond, Jared. 1997. Guns, Germs, and Steel: The Fates of Human Societies. W. W. Norton \& Co.

Englebert, Pierre. 2002. "Patterns and Theories of Traditional Resurgence in Tropical Africa." Mondes en développement 118:51-64.

Fearon, James D. 2006. Ethnic Mobilisation and Ethnic Violence. Oxford University Press pp. 852868.

Fortes, Meyer and Edward E. Evans-Pritchard, eds. 1940. African Political Systems. 1958 ed. Oxford University Press.

Gennaioli, Nicola and Ilia Rainer. 2007. “The Modern Impact of Precolonial Centralization in Africa." Journal of Economic Growth 12:185-234.

Gerring, John, Daniel Ziblatt, Johan Van Gorp and Julián Arévalo. 2011. “An Institutional Theory of Direct and Indirect Rule." World Politics 63(3):377-433.

Gerschewski, Johannes. 2020. “Explanations of Institutional Change: Reflecting on a "Missing Diagonal"." American Political Science Review p. 1-16.

Henn, Soeren J. 2020. “Complements or Substitutes: State Presence and the Power of Traditional Leaders." Unpublished Working Paper .

Herbst, Jeffrey. 2000. States and Power in Africa. Princeton University Press. 
Hicks, Ursula K. 1961. Development from below. Local Government and Finance in Developing Countries of the Commonwealth. Oxford University Press.

Holzinger, Katharina, Florian G Kern and Daniela Kromrey. 2017. Traditional Institutions in SubSaharan Africa: Endangering Or Promoting Stable Domestic Peace? Deutsche Stiftung Friedensforschung Research Report no. 42. Osnabrück.

Holzinger, Katharina, Roos Haer, Axel Bayer, Daniela M Behr and Clara Neupert-Wentz. 2019. "The constitutionalization of indigenous group rights, traditional political institutions, and customary law." Comparative Political Studies 52(12):1775-1809.

Huillery, Elise. 2010. “The impact of European settlement within French West Africa: Did precolonial prosperous areas fall behind?" Journal of African Economies 20(2):263-311.

Kromrey, Daniela. 2021. “Traditional Political Systems \& Index of Democraticness.”. URL: https://doi.org/10.7910/DVN/D15UZO

Logan, Carolyn. 2013. “The roots of resilience: Exploring popular support for African traditional authorities." African Affairs 112(448):353-376.

Mahoney, James and Kathleen Thelen. 2009. A Theory of Gradual Institutional Change. Cambridge University Press p. 1-37.

Mainga, Mutumba. 2010 [1973]. Bulozi under the Luyana kings: Political evolution and state formation in pre-colonial Zambia. Bookworld Publishers.

Mamdani, Mahmood. 1996. Citizen and Subject. Contemporary Africa and the Legacy of Late Colonialism. Princeton University Press.

Michalopoulos, Stelios and Elias Papaioannou. 2013. "Pre-Colonial Ethnic Institutions and Contemporary African Development." Econometrica 81(1):113-152.

Miles, William F. S. 1994. Hausaland Divided. Colonialism and Independence in Nigeria and Niger. Cornell University Press.

Müller-Crepon, Carl. 2020. “Continuity or Change? (In)direct Rule in British and French Colonial Africa." International Organization 74(4):707-741.

Müller-Crepon, Carl, Yannick I Pengl and Nils-Christian Bormann. 2020. “Linking Ethnic Data from Africa." Journal of Peace Research, forthcoming .

Murdock, George Peter. 1959. Africa. Its Peoples and Their Culture History. McGraw-Hill.

Murdock, George Peter. 1967. Ethnographic Atlas. University of Pittsburgh Press.

Mustasilta, Katariina. 2021. "The implications of traditional authority contest for local-level stability-Evidence from South Africa." Conflict Management and Peace Science 38(4):457-480.

Neupert-Wentz, Clara, Daniela Kromrey and Axel Bayer. 2021. “The democraticness of traditional political systems in Africa." Democratization pp. 1-24.

North, Douglass C. 1991. “Institutions." Journal of Economic Perspectives 5(1):97-112. 
Nunn, Nathan and Leonard Wantchekon. 2011. "The Slave Trade and the Origins of Mistrust in Africa." The American Economic Review 101(7):3221-3252.

Page, Scott E. 2006. "Path dependence." Quarterly Journal of Political Science 1(1):87-115.

Paine, Jack. 2019. "Ethnic Violence in Africa: Destructive Legacies of Pre-Colonial States." International Organization 73(3):645-683.

Ranger, Terence. 1968. "Nationality and Nationalism: the case of Barotseland." Journal of the Historical Society of Nigeria pp. 227-246.

Ranger, Terence. 1983. The Invention of Tradition in Colonial Africa. In The Invention of Tradition, ed. Eric Hobsbawm and Terence Ranger. Cambridge University Press pp. 211-262.

Reid, Richard J. 2002. Political Power in Pre-colonial Buganda: Economy, Society \& Warfare in the Nineteenth Century. James Currey.

Tobin, Joseph. 1990. “The HRAF as radical text?” Cultural anthropology 5(4):473-487.

Wig, Tore. 2016. "Peace from the Past: Pre-colonial Political Institutions and Civil Wars in Africa." Journal of Peace Research 53(4):509-524.

Wig, Tore and Daniela Kromrey. 2018. "Which groups fight? Customary institutions and communal conflicts in Africa." Journal of Peace Research 55(4):415-429.

Wilfahrt, Martha. 2018. "Precolonial legacies and institutional congruence in public goods delivery: Evidence from decentralized West Africa." World Politics 70(2):239-274.

Young, Crawford. 1994. The African Colonial State in Comparative Perspective. Yale University Press.

Zeller, Wolfgang and Henning Melber. 2019. United in Separation? Lozi Secessionism in Zambia and Namibia. Cham: Springer International Publishing pp. 293-328.

URL: https://doi.org/10.1007/978-3-319-90206-711 


\section{Online Appendix}

\section{Traditional Institutions in Africa, Past and Present}

\section{Table of Contents}

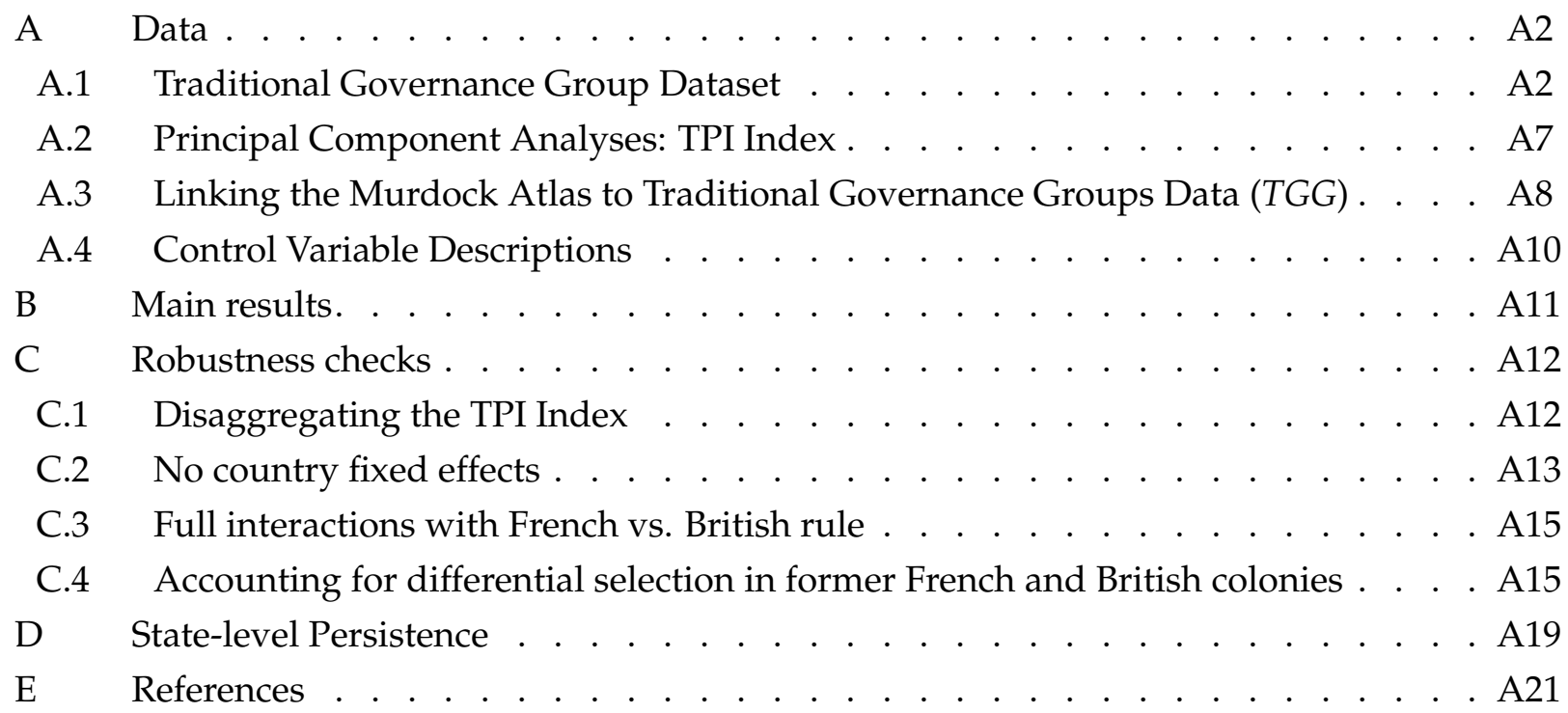




\section{A Data}

Table A1: Precolonial centralization and current TPIs: Summary Stats

\begin{tabular}{|c|c|c|c|c|c|}
\hline Statistic & $\mathrm{N}$ & Mean & St. Dev. & Min & Max \\
\hline TPI Index & 618 & 0.599 & 0.214 & 0.000 & 1.000 \\
\hline TPI Level & 636 & 0.555 & 0.362 & 0.000 & 1.000 \\
\hline Institution Index & 662 & 0.579 & 0.267 & 0.000 & 1.000 \\
\hline Leader Index & 662 & 0.483 & 0.249 & 0.000 & 1.000 \\
\hline Max Leader & 662 & 0.687 & 0.370 & 0.000 & 1.000 \\
\hline State-ties Index & 622 & 0.783 & 0.222 & 0.000 & 1.000 \\
\hline Functions Index & 643 & 0.677 & 0.222 & 0.000 & 1.000 \\
\hline Precol. centr. (v33) & 1,205 & 1.378 & 1.019 & 0.000 & 3.000 \\
\hline Population & 1,321 & $83,761.310$ & $263,798.200$ & $0.000 \quad 5$ & $5,948,205.000$ \\
\hline Area & 1,321 & 1.953 & 3.908 & 0.00000 & 43.779 \\
\hline Distance to coast & 1,320 & 611.708 & 445.370 & 2.116 & $1,783.130$ \\
\hline Distance to nav. river & 1,320 & 274.899 & 412.171 & 0.671 & $2,335.461$ \\
\hline Reliance on agriculture & 1,274 & 2.453 & 2.011 & 0.000 & 9.000 \\
\hline Reliance on pastoralism & 1,274 & 5.382 & 1.933 & 0.000 & 9.000 \\
\hline Intensity of agriculture & 1,215 & 2.304 & 0.838 & 0.000 & 4.000 \\
\hline Altitude & 1,321 & 614.760 & 447.576 & 2.667 & $2,899.750$ \\
\hline Ruggedness & 1,321 & 4.059 & 1.256 & 1.000 & 9.000 \\
\hline Temperature & 1,321 & 24.492 & 3.262 & 7.550 & 30.011 \\
\hline Evapotranspiration & 1,321 & $1,659.086$ & 290.233 & $1,085.276$ & $2,519.306$ \\
\hline Precipitation & 1,321 & $1,031.031$ & 596.754 & 0.071 & $3,147.643$ \\
\hline Precipitation/Evapotr. & 1,321 & 4.031 & 1.650 & 1.000 & 8.000 \\
\hline Agr. suitability & 1,311 & 0.327 & 0.246 & 0.000 & 0.985 \\
\hline Cash crop suitability & 1,320 & 0.329 & 0.166 & 0.000 & 0.824 \\
\hline Malaria environment & 1,321 & 0.583 & 0.201 & 0.00001 & 0.962 \\
\hline Tsetse environment & 1,321 & 0.495 & 0.438 & 0.000 & 1.000 \\
\hline
\end{tabular}

\section{A.1 Traditional Governance Group Dataset}

\section{A.1.1 Unit of Analysis and Data Collection}

For our measure of contemporary traditional institutions, we rely on the Traditional Governance Group (TGG) Dataset. The dataset is the result of a global online expert survey. Expert surveys are a frequently-used tool that allows for the systematic collection of data across a predefined set of observations. A prominent example of expert surveys data collection include the Ethnic Power Relations (EPR) data (Cederman, Wimmer and Min 2010) using a single expert per politically relevant ethnic group. Another example is the Varieties of Democracy (V-Dem) Project, using multiple experts for each country who code information across time (Coppedge et al. 2020). Additionally, the Ethnographic Atlas by Murdock (1967) is a form of an expert survey in this case, however, ethnic groups were coded on the basis of secondary sources from experts.

The universe of groups for the expert survey is mainly based on the All Minorities at Risk (AMAR) list of socially relevant ethnic groups (Birnir et al. 2014). Social relevance denotes that "people notice and condition their actions on ethnic distinctions in everyday life" (Fearon 2006, 852), but does not require any form of institutional or political organization.

On the basis of the group list, experts were chosen due to their (academic) publications, affiliations with ethnic groups, or through organizations that work on behalf of those groups. More than half of the experts who responded to the survey were academics, in particular ethnologists, 
anthropologists, historians, and political scientists.

Beyond the personalized invitations for experts for groups from that list, experts were free to add additional groups. In addition to the personalized invitations, organizations working with indigenous groups as well as the UN Expert Mechanism on the Rights of Indigenous peoples (EMRIP) distributed anonymous survey links in their networks. The final data is therefore based on an open-ended list of ethnic groups, lacking a clearly defined universe of cases. This further motivates the use Murdock's groups as our unit of analysis (1959; 1967).

\section{A.1.2 Inter-coder Reliability and Data Aggregation}

1,122 experts answered the survey for 746 African groups. Averaging at 1.5 experts per group, the number of experts per group ranges from 1 to 12 . Here, we inspect the inter-coder agreement. ${ }^{9}$ We present direct measures of inter-coder agreement in Table A2 on the basis of Equation A.1. We set a $90 \%$ benchmark for agreement. For binary variables this means that if at least $90 \%$ of the experts for a single group agree-for instance, on the existence of a customary court-we count the group observation as agreement. Similarly, for the 3-point ordinal variable TPI Level, we treat each level as a binary variable and thus require for agreement that $90 \%$ must agree on a particular level. For the two 5-point ordinal variables, we define agreement as assessments that are at most one point away from each other (for instance, $90 \%$ of experts picking levels 4 or 5 for a particular group).

Formally, for binary variables, we report

$$
\frac{1}{N} \sum_{i}\left\{\mathbb{1}\left(\frac{1}{n_{i}} \sum_{j} Y_{i j} \geq 0.9 \vee \frac{1}{n_{i}} \sum_{j} Y_{i j} \leq 0.1\right)\right\}
$$

where $N$ is the number of groups, $i$ indexes groups, $n_{i}$ is the number of experts for group $i$, $Y_{i j}$ is the value of variable $Y$ for group $i$ according to expert $j$, and $\mathbb{1}$ is the indicator function. The formulae for the ordinal variables are defined accordingly.

Table A2 shows all variables used in our analyses and the percentage of groups where $90 \%$ of the experts agree as described above. Overall agreement always exceeds $80 \%$, indicating high overall reliability between our experts.

In a second step, observations of groups with more than one expert rating were aggregated. The type of aggregation we use in our analysis incorporates the judgment of the coder and is done manually. In the case of divergent expert ratings, coders compared information given by different experts for one group using additional comments by the experts provided in the comment section of the survey and triangulated this with additional information if necessary. Furthermore, some experts mentioned leaders or institutions in the additional "Other leader" options, which actually fit the pre-specified categories of the survey items and are thus re-coded. Examples include village heads, which are re-coded as headmen, or "cacique," which is re-coded to chief. All coding and aggregation decisions are documented to allow for back-ward checking and will be published along with the TGG dataset.

\footnotetext{
${ }^{9}$ Note that inter-rater reliability statistics such as Cohen's kappa or Krippendorff's alpha are ill-suited for our data, due to the paradox of "high agreement but low reliability" (Feinstein and Cicchetti 1990; Cicchetti and Feinstein 1990). That is, in the case of highly skewed data (e.g., if a substantive part of the population has traditional institutions and many experts agree on their existence), such statistics may indicate low reliability when, in fact, the agreement among raters is high.
} 
Table A2: Intercoder agreement

\begin{tabular}{lc}
\hline \hline Variable & $\%$ Agreement \\
\hline Any TPI & $95.44 \%$ \\
TPI Level (ordinal, 3 point) & $82.18 \%$ \\
TPI Level (ordinal, 5 point) & $90.83 \%$ \\
Council of elders & $82.23 \%$ \\
King's council & $90.57 \%$ \\
Assembly & $81.92 \%$ \\
Customary court & $81.92 \%$ \\
Customary law, rules, and norms & $81.92 \%$ \\
King & $88.99 \%$ \\
Chief & $85.06 \%$ \\
Headman or Bandleader & $85.38 \%$ \\
Judge & $84.43 \%$ \\
Healer & $80.97 \%$ \\
Spiritual leader & $82.08 \%$ \\
Formal recognition & $92.12 \%$ \\
Personal ties (ordinal, 5 point) & $90.3 \%$ \\
Interaction through (in)formal bodies & $91.77 \%$ \\
TPI function: Land & $87.29 \%$ \\
TPI function: Natural resource mgt & $83.73 \%$ \\
TPI function: Culture & $86.27 \%$ \\
TPI function: Family matters & $88.31 \%$ \\
TPI function: Dispute resolution & $94.07 \%$ \\
TPI function: Health & $82.2 \%$ \\
TPI function: Security & $82.71 \%$ \\
TPI function: Spiritual matters & $81.86 \%$ \\
TPI function: Infrastructure & $84.92 \%$ \\
\hline N Experts & 1122 \\
N Groups & 746 \\
\hline \hline
\end{tabular}

Note: All variables are binary, unless marked otherwise. Percentage of groups with at least $90 \%$ agreement between experts.

\section{A.1.3 Variable Description}

\section{A.1.4 Survey Items}

\section{Institutions:}

TPI Level: Which level is the highest level where a traditional/ native/ indigenous organization (leaders, bodies, and rules) of the group X exists?

- Kingdom and/or paramount chieftaincy

- Regional: district-level/ several villages

- Local: village-level/ municipal-level/ clan-level/ band-level

- Pastoralist-level (nomads)

- The group is traditionally organized but is without a leader (acephalous)

- I do not know

Institution Index: Which forms of traditional/ indigenous/ native organization do the group $X$ in country $Y$ have? It may be the case that there is more than one leader or body for the group $X$. Please tick all the boxes that apply. 
- Council of elders

- King's council

- Traditional/ Indigenous/ Native (village) assembly

- Traditional/ Indigenous/ Native dispute resolution mechanisms and/or courts

- Traditional/ Indigenous/ Native customary rules and norms

- Other, namely (1)...

- Other, namely (2)...

- Other, namely (3)...

\section{Leaders:}

Which forms of traditional/ indigenous/ native organization do the group $\mathrm{X}$ in country $\mathrm{Y}$ have? It may be the case that there is more than one leader or body for the group X. Please tick all the boxes that apply. If there are leaders of one category on more than one hierarchical level (e.g. chiefs and sub-chiefs), please make use of the 'other' options to differentiate between these leaders.

- King/ Queen/ Paramount chief/ Emir

- Chief/ Khan/ Ariki/ Jif

- Headman/ Bandleader

- Traditional/ Indigenous/ Native judge

- Traditional/ Indigenous/ Native healer

- Traditional/ Indigenous/ Native spiritual leader

- Other, namely (1)...

- Other, namely (2)...

- Other, namely (3)...

- No leader (acephalous)

\section{Ties with the state:}

The measure for Ties comprises three variables of the original expert survey:

1: Recognition Is there a formal proceeding for acknowledgement of (at least one of) the leaders of the group $\mathrm{X}$ by state authorities?

- Yes

- No

- I do not know 
2: Personal Ties Do leaders of the group $X$ in country $Y$ have personal ties with politicians? If so, how many of them have these ties? E.g. they have family connections, business ties, or are close friends.

- All leaders have them

- Many leaders have them

- Some leaders have them

- Few leaders have them

- No leaders have them

- I do not know

3: Interaction through (in)formal bodies Are there (in)formal institutions in which the traditional/ indigenous/ native organization of the group $X$ interact with state authorities in country Y? E.g. land boards, commissions, national house of chiefs, etc.

- Yes, namely ... [String Var]

- No

- I do not know

\section{Functions:}

Which are the official and unofficial functions of the organization (leaders, bodies, and rules) of the group $X$ ? Please tick all the boxes that apply.

- Land administration

- Natural resource management

- Cultural matters (such as clothing, arts and crafts, language)

- Family matters (such as marriage, inheritance, burial matters)

- Dispute resolution

- Health (such as the use of traditional medicine)

- Security matters, peace and order (such as policing)

- Spiritual functions

- Infrastructural provisions (such as electricity, water, sanitation, and infrastructure)

- Other functions, namely...

- I do not know 


\section{A.2 Principal Component Analyses: TPI Index}

Table A3: PCA of group-level traditional institutions indicators

\begin{tabular}{llrlrrr}
\hline \hline & \multicolumn{7}{c}{ Component } \\
\cline { 2 - 7 } & $(1)$ & $(2)$ & $(3)$ & \multicolumn{1}{c}{$(4)$} & \multicolumn{1}{c}{$(5)$} & \multicolumn{1}{c}{$(6)$} \\
\hline Summary statistics: & & & & & & \\
$\quad$ Standard deviation & 1.744 & 1.052 & 0.879 & 0.647 & 0.614 & 0.533 \\
Proportion of Variance & 0.507 & 0.185 & 0.129 & 0.070 & 0.063 & 0.047 \\
Cumulative Proportion & 0.507 & 0.691 & 0.820 & 0.890 & 0.953 & 1.000 \\
\hline Factor loadings: & & & & & & \\
$\quad$ TPI Level & 0.407 & -0.439 & 0.292 & -0.628 & -0.250 & -0.316 \\
Institution Index & 0.450 & 0.397 & 0.041 & -0.039 & -0.550 & 0.578 \\
Leader Index & 0.480 & 0.206 & 0.049 & 0.562 & -0.149 & -0.622 \\
$\quad$ Max Leader & 0.433 & -0.273 & 0.448 & 0.262 & 0.570 & 0.379 \\
State-ties Index & 0.253 & -0.587 & -0.714 & 0.208 & -0.115 & 0.161 \\
Functions Index & 0.387 & 0.434 & -0.449 & -0.420 & 0.523 & -0.097 \\
\hline
\end{tabular}


Relation among indeces of contemporary TPIs in Murdock groups

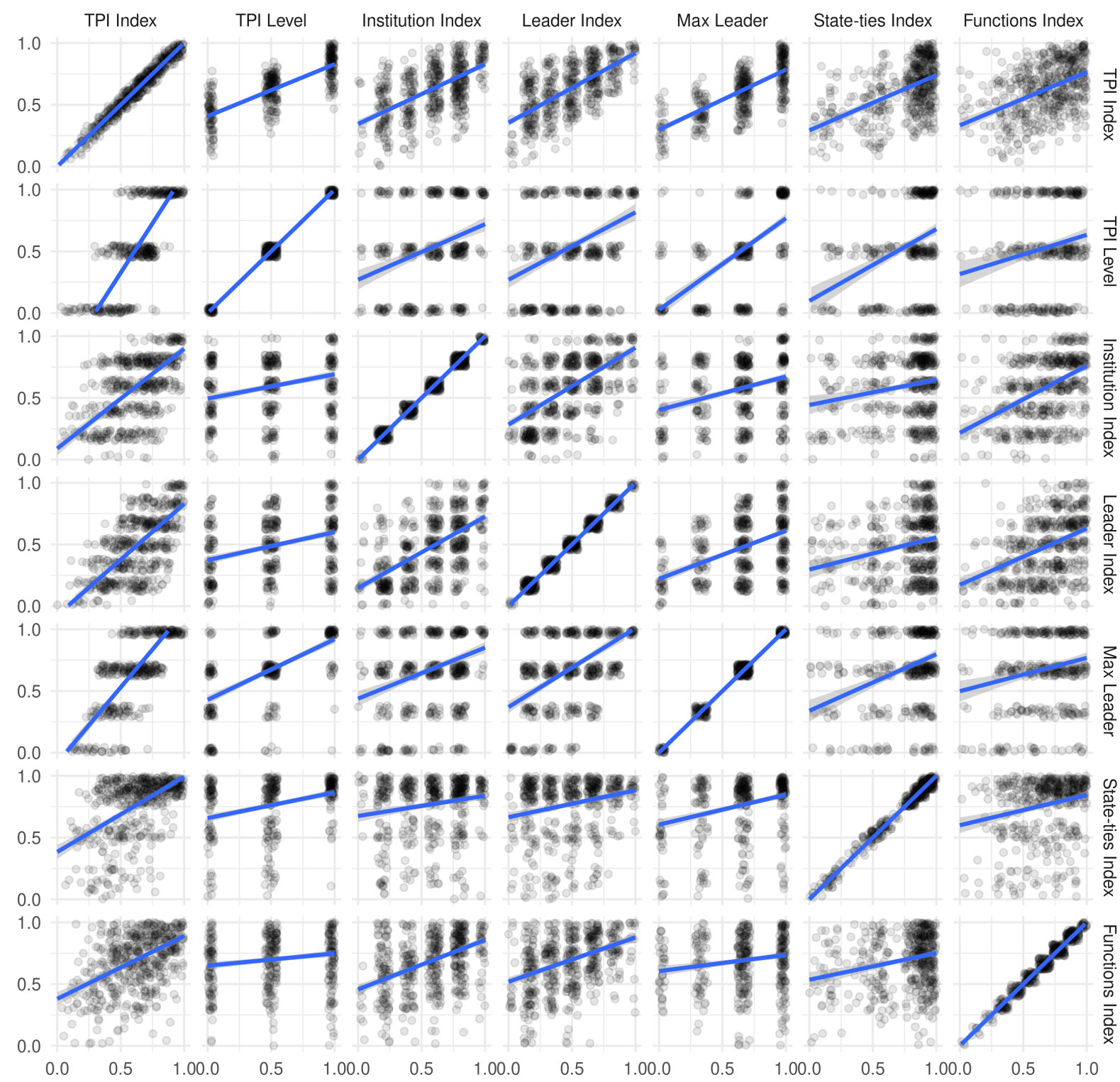

Figure A1: Correlations among the main group-level TPI variables.

\section{A.3 Linking the Murdock Atlas to Traditional Governance Groups Data (TGG)}

We link the TGG to the Murdock data in order to analyze the relationship between Murdock's coding of precolonial political centralization and data on contemporary traditional institutions. To do so in a coherent and replicable manner, we draw on a new technique that leverages the universe of known languages to link datasets on ethnic groups in Africa to each other. Drawing on Müller-Crepon, Pengl and Bormann (2020), our matching procedure consists linking each ethnic group in the TGG and Murdock datasets with the list of languages provided by Ethnologue (Lewis 2009). In a second step, we link each group from the TGG and Murdock data if they have at least one language in common and are coded to be present in the same contemporary country. ${ }^{10}$ The research project led by Müller-Crepon, Pengl and Bormann (2020) provides the data on the links between Ethnologue and the Murdock and TGG data that are necessary to

\footnotetext{
${ }^{10}$ Murdock groups are linked to countries via their geographic settlement area derived from Murdock (1959).
} 
implement these two steps.

Because linguistic groups are most often nested within ethnic groups encoded in our datasets, the matching procedure produces consistent results. There are relatively few groupssuch as the Hutu and Tutsi in Rwanda or the various Somali subgroups on the Horn-where several groups speak the same language. In these cases, our matching is imprecise, but unlikely to introduce systematic bias.

The first step of the coding is successful, with more than $95 \%$ of groups in both datasets linked to one or more languages from the Ethnologue data. In the second step, we are able to match $579(84.3 \%)$ groups from the TGG data to a total of $731(55.3 \%)$ groups enumerated by Murdock. As a result of the fact that Murdock and the TGG data enumerate ethnic groups in different manners, the resulting matching is many-to-many, that is, some TGG groups are linked to several groups from Murdock's data and vice-versa. It is therefore necessary to collapse the data on groups from the TGG data that are linked to the same Murdock group. We do so by taking the average of the variables presented above.

Table A4 presents the results of a descriptive analysis of the attributes of Murdock groups that lack a link to the TGG data. The results show that small groups and those colonized by Portugal or Belgium are least likely to be associated with a counterpart in the TGG data. Importantly, the probability of being matched is, if at all, only marginally higher for centralized groups. 
Table A4: Covariates of successful link between Murdock and TradGovGroup data

\begin{tabular}{|c|c|c|c|c|c|}
\hline & \multicolumn{5}{|c|}{ Matched Murdock Group (0/1) } \\
\hline & $(1)$ & $(2)$ & (3) & $(4)$ & $(5)$ \\
\hline Constant & $\begin{array}{c}0.178^{* *} \\
(0.082)\end{array}$ & $\begin{array}{l}0.623^{* * *} \\
(0.023)\end{array}$ & $\begin{array}{l}0.521^{* * *} \\
(0.024)\end{array}$ & $\begin{array}{l}0.626^{* * *} \\
(0.046)\end{array}$ & $\begin{array}{c}0.178^{*} \\
(0.103)\end{array}$ \\
\hline Population (1880; log) & $\begin{array}{l}0.041^{* * *} \\
(0.008)\end{array}$ & & & & $\begin{array}{l}0.046^{\text {*** }} \\
(0.009)\end{array}$ \\
\hline Area $(\log )$ & $\begin{array}{l}0.042^{* * *} \\
(0.008)\end{array}$ & & & & $\begin{array}{l}0.041^{\text {*** }} \\
(0.008)\end{array}$ \\
\hline Split $(0 / 1)$ & & $\begin{array}{c}-0.108^{* * *} \\
(0.028)\end{array}$ & & & $\begin{array}{c}-0.013 \\
(0.030)\end{array}$ \\
\hline Precol. Centr. (v33) & & & $\begin{array}{c}0.026^{*} \\
(0.014)\end{array}$ & & $\begin{array}{c}0.007 \\
(0.013)\end{array}$ \\
\hline Belgian colony & & & & $\begin{array}{c}-0.216^{* * *} \\
(0.064)\end{array}$ & $\begin{array}{c}-0.226^{* * *} \\
(0.064)\end{array}$ \\
\hline British colony & & & & $\begin{array}{r}-0.009 \\
(0.050)\end{array}$ & $\begin{array}{c}0.026 \\
(0.050)\end{array}$ \\
\hline French colony & & & & $\begin{array}{r}-0.100^{*} \\
(0.051)\end{array}$ & $\begin{array}{r}-0.081 \\
(0.051)\end{array}$ \\
\hline Portuguese colony & & & & $\begin{array}{c}-0.303^{* * *} \\
(0.076)\end{array}$ & $\begin{array}{c}-0.274^{* * *} \\
(0.078)\end{array}$ \\
\hline Observations & 1,321 & 1,321 & 1,205 & 1,321 & 1,205 \\
\hline Adjusted $\mathrm{R}^{2}$ & 0.090 & 0.010 & 0.002 & 0.025 & 0.128 \\
\hline
\end{tabular}

\section{A.4 Control Variable Descriptions}

Baseline: To control for the geography and location of ethnic groups, we add their population size, estimated for the year 1880 (Goldewijk, Beusen and Janssen 2010), their area, their distance to the coast as well as to the closest navigable river. ${ }^{11}$ These measures are all logged to reduce their right-skew.

Ethnic: Since precolonial agriculture might have been an important driver of political centralization (e.g. Fenske 2013), we add variables that capture the extent to which ethnic groups relied on agriculture and husbandry, as well as an indicator of the intensity of agriculture in a group. These variables are encoded in the Ethnographic Atlas (Murdock 1967).

Nature: Lastly, we control for a vector of characteristics of the natural environment of ethnic groups, which might have influenced their prosperity and propensity for political centralization. These variables consist of the altitude, temperature, precipitation and evapotranspiration, the ratio of the two, agricultural suitability, and soils' suitability for cash crop

\footnotetext{
${ }^{11}$ Data on navigable rivers comes from Jedwab and Moradi (2016).
} 
production, ${ }^{12}$ as well as the local disease environment regarding malaria ${ }^{13}$ and the Tsetse fly. ${ }^{14}$

\section{B Main results}

Table A5 shows the estimates of Eq. (1) and is the basis of the first block in Figure 3 in the main text. The main results show a robust positive relationship between precolonial levels of political centralization and our index of current levels of institutionalization of traditional governance.

Table A5: Precolonial centralization and current TPI Index

\begin{tabular}{lllll}
\hline \hline & \multicolumn{3}{c}{ TPI Index } \\
\cline { 2 - 5 } & $(1)$ & $(2)$ & $(3)$ & $(4)$ \\
\hline Precol. centralization (v33) & $0.043^{* * *}$ & $0.040^{* * *}$ & $0.038^{* * *}$ & $0.036^{* * *}$ \\
& $(0.010)$ & $(0.010)$ & $(0.009)$ & $(0.010)$ \\
\hline Baseline covariates & & yes & yes & yes \\
Ethnic covariates & no & no & yes & yes \\
Nature covariates & no & no & no & yes \\
Country (2016) FEs & yes & yes & yes & yes \\
Observations & 566 & 566 & 566 & 566 \\
Adjusted R & 0.417 & 0.425 & 0.424 & 0.426 \\
\hline \hline
\end{tabular}

Notes: OLS models. Standard errors are clustered on the ethnic group level. Significance codes: ${ }^{*} \mathrm{p}<0.1$; ${ }^{* *} \mathrm{p}<0.05 ;{ }^{* * *} \mathrm{p}<0.01$.

Table A6 tests the the interaction of precolonial centralization and French and British colonial rule (Eq. (2)). The correlation between precolonial centralization and our TPI Index is almost exclusively driven by ethnic groups in former British, rather than French colonies. The coefficient v33 $\times$ British is slightly larger than estimated on the entire sample in Table A5 and statistically highly significant (Panel 2 in Figure 3). In former French colonies, the relationship between past levels of centralization and the TPI Index is estimated to be close to zero (Panel 3 in Figure 3). The difference between the two estimates (Panel 4 in Figure 3)is significant in the first three specifications but turns statistically insignificant once we add all control variables.

In addition to greater continuity under British rule, the first coefficient, British, has a consistent positive sign. This suggests that former British rule is associated with generally more institutionalized traditional authorities of previously acephalous groups ("upgrading"). This estimate is however based only on variation from within today's Cameroon, the only country with areas colonized by the British and the French. The effect does not hold once we remove the country fixed effects (see subsection C.2). We, therefore, conclude that there is no robust evidence for generally higher levels of institutionalization of formerly decentralized traditional authorities in former British colonies.

\footnotetext{
${ }^{12}$ These variables come from the FAO's (2015) GAEZ database. The cash crop suitability is calculated as the local max of soils' suitability for the production of the eight most prominent cash crops, in particular coffee, cotton, cocoa, groundnuts, oil palms, sugarcane, tea, and tobacco.

${ }^{13}$ This is a temperature-based index from Gething et al. (2011).

${ }^{14}$ Data from the Programme Against African Trypanosomosis (1999).
} 
Table A6: Precolonial centralization and current TPIs in former British and French colonies

\begin{tabular}{|c|c|c|c|c|}
\hline & \multicolumn{4}{|c|}{ TPI Index } \\
\hline & $(1)$ & $(2)$ & (3) & $(4)$ \\
\hline British & $\begin{array}{l}0.168^{* *} \\
(0.068)\end{array}$ & $\begin{array}{c}0.129^{*} \\
(0.068)\end{array}$ & $\begin{array}{l}0.138^{* *} \\
(0.066)\end{array}$ & $\begin{array}{l}0.233^{\text {*** }} \\
(0.081)\end{array}$ \\
\hline Precol. centr. (v33) $\times$ British & $\begin{array}{l}0.054^{* * *} \\
(0.013)\end{array}$ & $\begin{array}{l}0.051^{* * *} \\
(0.013)\end{array}$ & $\begin{array}{l}0.046^{* * *} \\
(0.011)\end{array}$ & $\begin{array}{l}0.041^{\text {*** }} \\
(0.012)\end{array}$ \\
\hline Precol. centr. (v33) × French & $\begin{array}{c}0.018 \\
(0.016)\end{array}$ & $\begin{array}{c}0.010 \\
(0.017)\end{array}$ & $\begin{array}{c}0.011 \\
(0.018)\end{array}$ & $\begin{array}{c}0.012 \\
(0.018)\end{array}$ \\
\hline British-French Diff.: & $\begin{array}{c}0.035^{*} \\
(0.021) \\
\end{array}$ & $\begin{array}{c}0.041^{*} \\
(0.021) \\
\end{array}$ & $\begin{array}{c}0.035^{*} \\
(0.02)\end{array}$ & $\begin{array}{c}0.029 \\
(0.02) \\
\end{array}$ \\
\hline Baseline covariates & no & yes & yes & yes \\
\hline Ethnic covariates & no & no & yes & yes \\
\hline Nature covariates & no & no & no & yes \\
\hline Country (2016) FEs & yes & yes & yes & yes \\
\hline Mean DV: & 0.6 & 0.6 & 0.6 & 0.6 \\
\hline Observations & 455 & 455 & 455 & 455 \\
\hline Adjusted $\mathrm{R}^{2}$ & 0.458 & 0.467 & 0.466 & 0.476 \\
\hline
\end{tabular}

Notes: OLS models. Standard errors are clustered on the ethnic group level. Significance codes: ${ }^{*} \mathrm{p}<0.1$; ${ }^{* *} \mathrm{p}<0.05{ }^{* * *} \mathrm{p}<0.01$.

\section{Robustness checks}

\section{C.1 Disaggregating the TPI Index}

In Figure 2 of the main text we plot the respective estimates across colonies. Here we look at the long-term effect of British vs. French rule across the outcomes. The aggregate results on institutional persistence and the effect of British vs. French rule on institutional persistence can thus be qualified by looking at its relation to the single indicators on traditional institutions that are used to create the TPI Index. Figure A2 plots the estimates differentiating between former British and French colonies. It emerges that British rule leads to a stronger correlation of past levels of centralization with the number of traditional institutions captured by the Institutions Index, the number and strength of ties between traditional authorities and the state (State-ties Index, as well as the extent of their functions and responsibilities (Functions Index). It is mostly in the realm of our measures of the number and existing hierarchy of contemporary traditional leaders that levels of persistence in former French and British colonies do not differ much from each other. 


\section{Long-term effect of British vs. French rule}

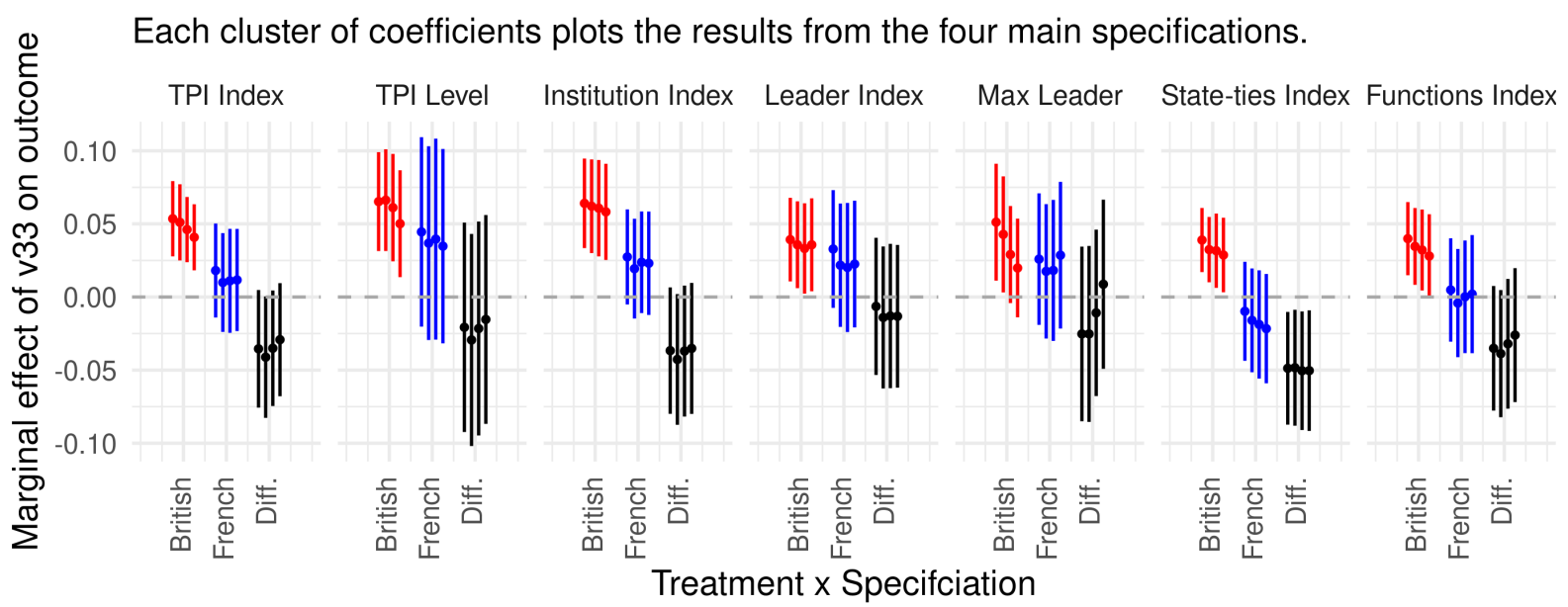

Figure A2: Effect of precolonial centralization (Murdock's v33) on all current outcomes in former British and French colonies.

Note: The four coefficients in each cluster correspond (from left to right) to Specifications 1 to 4 reported in Table A6.

\section{C.2 No country fixed effects}

Table A7: Precolonial centralization and current TPI Index: No fixed effects

\begin{tabular}{lllll}
\hline \hline & \multicolumn{3}{c}{ TPI Index } \\
\cline { 2 - 5 } & $(1)$ & $(2)$ & $(3)$ & $(4)$ \\
\hline Precol. centralization (v33) & $0.028^{* * *}$ & $0.031^{* * *}$ & $0.045^{* * *}$ & $0.051^{* * *}$ \\
& $(0.010)$ & $(0.009)$ & $(0.010)$ & $(0.010)$ \\
\hline Baseline covariates & & & & yes \\
Ethnic covariates & no & yes & yes & yes \\
Nature covariates & no & no & no & yes \\
Country (2016) FEs & no & no & no & no \\
Observations & no & 566 & 566 & 566 \\
Adjusted R & 566 & 0.091 & 0.120 & 0.155 \\
\hline \hline
\end{tabular}

Notes: OLS models. Standard errors are clustered on the ethnic group level. Significance codes: ${ }^{*} \mathrm{p}<0.1$; ${ }^{* *} \mathrm{p}<0.05 ;{ }^{* * *} \mathrm{p}<0.01$. 
Table A8: Precolonial centralization and current TPIs in former British and French colonies

\begin{tabular}{|c|c|c|c|c|}
\hline & \multicolumn{4}{|c|}{ TPI Index } \\
\hline & $(1)$ & $(2)$ & (3) & $(4)$ \\
\hline Constant & $\begin{array}{l}0.588^{* * *} \\
(0.026)\end{array}$ & $\begin{array}{l}0.601^{* * *} \\
(0.125)\end{array}$ & $\begin{array}{l}0.567^{* * *} \\
(0.123)\end{array}$ & $\begin{array}{c}0.467^{* *} \\
(0.213)\end{array}$ \\
\hline British & $\begin{array}{r}-0.045 \\
(0.036)\end{array}$ & $\begin{array}{r}-0.031 \\
(0.034)\end{array}$ & $\begin{array}{c}-0.008 \\
(0.034)\end{array}$ & $\begin{array}{c}0.029 \\
(0.036)\end{array}$ \\
\hline Precol. centr. (v33) $\times$ British & $\begin{array}{l}0.056^{* * *} \\
(0.014)\end{array}$ & $\begin{array}{l}0.047^{* * *} \\
(0.013)\end{array}$ & $\begin{array}{l}0.051^{* * *} \\
(0.013)\end{array}$ & $\begin{array}{l}0.055^{* * *} \\
(0.013)\end{array}$ \\
\hline Precol. centr. $(v 33) \times$ French & $\begin{array}{r}-0.016 \\
(0.016)\end{array}$ & $\begin{array}{c}0.006 \\
(0.015)\end{array}$ & $\begin{array}{c}0.027^{*} \\
(0.016)\end{array}$ & $\begin{array}{c}0.030^{*} \\
(0.016)\end{array}$ \\
\hline British-French Diff.: & $\begin{array}{l}0.072^{* * *} \\
(0.021)\end{array}$ & $\begin{array}{l}0.042^{\text {** }} \\
(0.02)\end{array}$ & $\begin{array}{c}0.024 \\
(0.02) \\
\end{array}$ & $\begin{array}{c}0.024 \\
(0.02) \\
\end{array}$ \\
\hline Baseline covariates & no & yes & yes & yes \\
\hline Ethnic covariates & no & no & yes & yes \\
\hline Nature covariates & no & no & no & yes \\
\hline Country (2016) FEs & no & no & no & no \\
\hline Mean DV: & 0.6 & 0.6 & 0.6 & 0.6 \\
\hline Observations & 455 & 455 & 455 & 455 \\
\hline Adjusted $R^{2}$ & 0.056 & 0.154 & 0.176 & 0.208 \\
\hline
\end{tabular}

Notes: OLS models. Standard errors are clustered on the ethnic group level. Significance codes: ${ }^{*} \mathrm{p}<0.1$; ${ }^{* *} \mathrm{p}<0.05 ;{ }^{* * *} \mathrm{p}<0.01$. 


\section{C.3 Full interactions with French vs. British rule}

Table A9: Former British and French colonies: Full interactions

\begin{tabular}{|c|c|c|c|c|}
\hline & \multicolumn{4}{|c|}{ TPI Index } \\
\hline & $(1)$ & $(2)$ & (3) & $(4)$ \\
\hline British & $\begin{array}{l}0.168^{* *} \\
(0.068)\end{array}$ & $\begin{array}{r}-0.068 \\
(0.285)\end{array}$ & $\begin{array}{r}-0.165 \\
(0.287)\end{array}$ & $\begin{array}{r}-0.795 \\
(0.614)\end{array}$ \\
\hline Precol. centr. $(v 33) \times$ British & $\begin{array}{l}0.054^{* * *} \\
(0.013)\end{array}$ & $\begin{array}{l}0.048^{\text {*** }} \\
(0.014)\end{array}$ & $\begin{array}{l}0.039^{* * *} \\
(0.012)\end{array}$ & $\begin{array}{l}0.038^{* * *} \\
(0.012)\end{array}$ \\
\hline Precol. centr. $(v 33) \times$ French & $\begin{array}{c}0.018 \\
(0.016)\end{array}$ & $\begin{array}{c}0.016 \\
(0.017)\end{array}$ & $\begin{array}{c}0.012 \\
(0.019)\end{array}$ & $\begin{array}{c}0.008 \\
(0.019)\end{array}$ \\
\hline British-French Diff.: & $\begin{array}{c}0.035^{*} \\
(0.021)\end{array}$ & $\begin{array}{c}0.032 \\
(0.021)\end{array}$ & $\begin{array}{c}0.028 \\
(0.021)\end{array}$ & $\begin{array}{c}0.03 \\
(0.022) \\
\end{array}$ \\
\hline Baseline $\times$ British covariates & no & yes & yes & yes \\
\hline Ethnic $\times$ British covariates & no & no & yes & yes \\
\hline Nature $\times$ British covariates & no & no & no & yes \\
\hline Country (2016) FEs & yes & yes & yes & yes \\
\hline Mean DV: & 0.6 & 0.6 & 0.6 & 0.6 \\
\hline Observations & 455 & 455 & 455 & 455 \\
\hline Adjusted $\mathrm{R}^{2}$ & 0.458 & 0.469 & 0.474 & 0.472 \\
\hline
\end{tabular}

Notes: OLS models. Standard errors are clustered on the ethnic group level. Significance codes: ${ }^{*} \mathrm{p}<0.1$; ${ }^{* *} \mathrm{p}<0.05 ;{ }^{* * *} \mathrm{p}<0.01$.

\section{C.4 Accounting for differential selection in former French and British colonies}

A concern with our data could be that (1) non-matches between Murdock and the TGG and (2) missingness in the TGG data lead to selection bias. It may be that missing matches and missing data are, in fact, an indication for institutional change-in the form of destruction and death of an institution - that we do not account for in our analysis. Importantly, we need to make sure that our findings that persistence is driven by groups in former British colonies is not based on differential selection into the sample and thus an artefact of selection bias. We analyse both selection stages separately below and then account for differential selection in an extension of our main analysis.

\section{C.4.1 Selection stage}

Our data allows us to partially assess the potential for bias due to missingness in the outcome variable. Two selection stages can introduce bias in our estimates. First, we consider missingness due to non-matches between Murdock the TGG dataset, and second, we take missing data within the TGG dataset into account.

After accounting for missing data on our covariates, the initial sample of Murdock groups from French and British colonies consists of 899 groups. This count includes groups that we split so that they are nested within country borders. After matching with the TGG data, we are left with 524 observations. Note that while the non-matching rate appears to be high, the non-matches consist of many small groups, frequently split across country borders. Table A4 
in Appendix A.3 shows that increases in the area and the logged population (in 1880) by $100 \%$ increases the chance of being matched by $4-5 \%$, respectively.

The match between the Murdock and the TGG data-described in Appendix A.3-can introduce bias if there is systematic missingness of groups in the population of the TGG data as a result of groups not appearing in the baseline population provided by AMAR (Birnir et al. 2014) or due to the absence or non-response of experts on specific groups.

We empirically examine the selection into the sample in Table A10. The unit of analysis are all Murdock groups in French and British colonies and the outcome is a dummy variable indicating whether there is a match between the Murdock group and the TGG in the respective country. The interaction term v33 $\times$ British does not have an effect on the probability of being matched. Yet, the interaction term between $v 33 \times$ French is negative and turns significant once we introduce control variables (Models 2-4). Hence, during the matching, we tend to drop centralized groups in former French colonies.

Table A10: Selection stage 1: Selection into sample of Murdock groups matched to TradGovGroups

\begin{tabular}{|c|c|c|c|c|}
\hline & \multicolumn{4}{|c|}{ Match of Murdock group with TradGov group } \\
\hline & $(1)$ & $(2)$ & $(3)$ & $(4)$ \\
\hline British & $\begin{array}{c}-0.426^{* * *} \\
(0.118)\end{array}$ & $\begin{array}{c}-0.376^{\text {*** }} \\
(0.118)\end{array}$ & $\begin{array}{c}-0.368^{* * *} \\
(0.120)\end{array}$ & $\begin{array}{c}-0.341^{\text {*** }} \\
(0.124)\end{array}$ \\
\hline Precol. centr. (v33) × British & $\begin{array}{c}0.012 \\
(0.022)\end{array}$ & $\begin{array}{c}-0.008 \\
(0.021)\end{array}$ & $\begin{array}{c}-0.020 \\
(0.023)\end{array}$ & $\begin{array}{c}-0.021 \\
(0.024)\end{array}$ \\
\hline Precol. centr. (v33) $\times$ French & $\begin{array}{r}-0.038 \\
(0.028)\end{array}$ & $\begin{array}{c}-0.053^{* *} \\
(0.026)\end{array}$ & $\begin{array}{c}-0.057^{* *} \\
(0.027)\end{array}$ & $\begin{array}{c}-0.063^{* *} \\
(0.027)\end{array}$ \\
\hline British-French Diff.: & $\begin{array}{c}0.05 \\
(0.034)\end{array}$ & $\begin{array}{c}0.045 \\
(0.033) \\
\end{array}$ & $\begin{array}{c}0.037 \\
(0.034)\end{array}$ & $\begin{array}{c}0.042 \\
(0.035)\end{array}$ \\
\hline Baseline covariates & no & yes & yes & yes \\
\hline Ethnic covariates & no & no & yes & yes \\
\hline Nature covariates & no & no & no & yes \\
\hline Country (2016) FEs & yes & yes & yes & yes \\
\hline Mean DV: & 0.58 & 0.58 & 0.58 & 0.57 \\
\hline Observations & 939 & 939 & 939 & 936 \\
\hline Adjusted $\mathrm{R}^{2}$ & 0.127 & 0.220 & 0.221 & 0.228 \\
\hline
\end{tabular}

Notes: OLS models. Standard errors are clustered on the ethnic group level. Significance codes: ${ }^{*} \mathrm{p}<0.1$; ${ }^{* *} \mathrm{p}<0.05 ;{ }^{* * *} \mathrm{p}<0.01$.

We continue with the second selection stage, which accounts for selection introduced by missing data in the TGG dataset. The variables of interest for our study (see data section) are conditional on a question that asks the expert whether "the group $X$ in country $Y$ currently has any form of traditional/ indigenous/ native organization?"15 When experts answer that groups have no type of contemporary traditional organization, they did not receive any questions on the institutional set-up of the group, resulting in missing values in our data. Again, rather than being true missing values, they could indicate that the groups' institutions have been destroyed

\footnotetext{
${ }^{15}$ The following information was additionally provided: "E.g. chiefs, elders, customary courts or rules and regulations such as customary land administration and customary jurisdiction. It might be the case that the group consists of several subgroups, families, clans or other smaller entities. Nevertheless, try to answer this question for the entire group. Furthermore, we do not consider non-governmental organizations, interest groups, or political parties as traditional authorities."
} 
or vanished, i.e. being ' $0 \mathrm{~s}^{\prime}$. We examine the correlates of such missingness by looking at all groups matched between the EA and the TGG. The outcome variable in Table A11 is a dummy indicating whether the expert(s) answer that there is any type of traditional organization, which is true for 441 out of the 524 matched observations.

Again, we do not see any effect of the interaction term between v33 $\times$ British. In this case, we, however, observe a positive and significant effect v33 $\times$ French on the outcome that the group has any traditional political organization, an estimate that has the opposite sign of the finding in the previous table. Hence, less centralized groups in French colonies are more likely to have missing data than centralized groups.

Table A11: Selection stage 2: Selection into non-missing data on traditional institutions

\begin{tabular}{|c|c|c|c|c|}
\hline & \multicolumn{4}{|c|}{ Any TPI } \\
\hline & (1) & (2) & (3) & (4) \\
\hline British & $\begin{array}{l}0.077^{* *} \\
(0.037)\end{array}$ & $\begin{array}{c}0.083^{*} \\
(0.044)\end{array}$ & $\begin{array}{c}0.042 \\
(0.048)\end{array}$ & $\begin{array}{c}0.169^{* *} \\
(0.066)\end{array}$ \\
\hline Precol. centr. (v33) $\times$ British & $\begin{array}{r}-0.017 \\
(0.016)\end{array}$ & $\begin{array}{c}-0.019 \\
(0.017)\end{array}$ & $\begin{array}{c}-0.013 \\
(0.020)\end{array}$ & $\begin{array}{c}-0.003 \\
(0.019)\end{array}$ \\
\hline Precol. centr. $(v 33) \times$ French & $\begin{array}{l}0.053^{* *} \\
(0.025)\end{array}$ & $\begin{array}{c}0.055^{* *} \\
(0.025)\end{array}$ & $\begin{array}{l}0.061^{* *} \\
(0.024)\end{array}$ & $\begin{array}{l}0.066^{* * *} \\
(0.023)\end{array}$ \\
\hline British-French Diff.: & $\begin{array}{c}-0.07^{* * *} \\
(0.03)\end{array}$ & $\begin{array}{c}-0.073^{* * *} \\
(0.03)\end{array}$ & $\begin{array}{c}-0.074^{* * *} \\
(0.031)\end{array}$ & $\begin{array}{c}-0.068^{* * *} \\
(0.028)\end{array}$ \\
\hline Baseline covariates & no & yes & yes & yes \\
\hline Ethnic covariates & no & no & yes & yes \\
\hline Nature covariates & no & no & no & yes \\
\hline Country (2016) FEs & yes & yes & yes & yes \\
\hline Mean DV: & 0.9 & 0.9 & 0.9 & 0.91 \\
\hline Observations & 540 & 540 & 540 & 537 \\
\hline Adjusted $\mathrm{R}^{2}$ & 0.287 & 0.290 & 0.306 & 0.314 \\
\hline
\end{tabular}

Notes: OLS models. Standard errors are clustered on the ethnic group level. Significance codes: ${ }^{*} \mathrm{p}<0.1$; ${ }^{* *} \mathrm{p}<0.05 ;{ }^{* * *} \mathrm{p}<0.01$.

We combine the selection stages one and two in Table A12. Therefore, our outcome variable here is a dummy variable indicating whether the group is selected in stages one and two, i.e., is successfully matched and non-missing in the TGG data. When combined, the interaction term v33 $\times$ French loses significance with a small point estimate. Because the selection effects cancel each other out, we no longer see any effects of the respective interaction terms across the two selection stages. Furthermore, there is no significant difference between French and British colonies.

Hence, our main independent variables of interest - the interactions between colonizer and precolonial centralization (v33) - do not significantly or differentially (in French and British colonies) impact on the selection of a group into our final dataset. Although in this context, small regression coefficients do not necessarily imply the absence of selection bias (Aronow, Baron and Pinson 2019), we take this result as evidence that the bias is likely to be small. 
Table A12: Selection stage 1 + 2: Selection of Murdock groups into final sample

\begin{tabular}{|c|c|c|c|c|}
\hline & \multicolumn{4}{|c|}{ Murdock group in final sample } \\
\hline & $(1)$ & $(2)$ & $(3)$ & $(4)$ \\
\hline British & $\begin{array}{l}-0.405^{* * *} \\
(0.118)\end{array}$ & $\begin{array}{l}-0.325^{* * *} \\
(0.118)\end{array}$ & $\begin{array}{l}-0.329^{* * *} \\
(0.118)\end{array}$ & $\begin{array}{c}-0.312^{* *} \\
(0.125)\end{array}$ \\
\hline Precol. centr. (v33) $\times$ British & $\begin{array}{c}0.012 \\
(0.022)\end{array}$ & $\begin{array}{c}-0.009 \\
(0.021)\end{array}$ & $\begin{array}{c}-0.015 \\
(0.024)\end{array}$ & $\begin{array}{r}-0.007 \\
(0.025)\end{array}$ \\
\hline Precol. centr. (v33) $\times$ French & $\begin{array}{c}-0.009 \\
(0.027)\end{array}$ & $\begin{array}{c}-0.020 \\
(0.026)\end{array}$ & $\begin{array}{c}-0.021 \\
(0.026)\end{array}$ & $\begin{array}{r}-0.028 \\
(0.027)\end{array}$ \\
\hline British-French Diff.: & $\begin{array}{c}0.022 \\
(0.033)\end{array}$ & $\begin{array}{c}0.011 \\
(0.032)\end{array}$ & $\begin{array}{c}0.006 \\
(0.034)\end{array}$ & $\begin{array}{c}0.021 \\
(0.036)\end{array}$ \\
\hline Baseline covariates & no & yes & yes & yes \\
\hline Ethnic covariates & no & no & yes & yes \\
\hline Nature covariates & no & no & no & yes \\
\hline Country (2016) FEs & yes & yes & yes & yes \\
\hline Mean DV: & 0.53 & 0.53 & 0.53 & 0.54 \\
\hline Observations & 939 & 939 & 939 & 936 \\
\hline Adjusted $\mathrm{R}^{2}$ & 0.137 & 0.221 & 0.221 & 0.218 \\
\hline
\end{tabular}

Notes: OLS models. Standard errors are clustered on the ethnic group level. Significance codes: ${ }^{*} \mathrm{p}<0.1$; ${ }^{* *} \mathrm{p}<0.05{ }^{* * *} \mathrm{p}<0.01$.

\section{C.4.2 Accounting for selection}

We continue by accounting for selection in our main models. First, we do so by re-running our main analysis, weighting observations with their inverse probability to be selected into the final dataset, estimates with a logit model based on all independent variables used in our main analysis. The results (Table A13) here are very similar to our main results and additionally benefit from "double-robustness" (Wooldridge 2007).

In a second step, we test whether our main finding holds if all missings generated in both selection stages were, in fact, indicators of the absence of any institutions on the group level. Hence, in Table A14, we code the TPI Index for all missing groups in both selection stages as being zero. The results are broadly consistent with our main findings. The point estimate of v33 $\times$ British is slightly smaller compared to our main models, which is not surprising given the stark increase of zeros in the sample. 
Table A13: Former British vs. French colonies: Reweighting by estimated 'selection' probability

\begin{tabular}{|c|c|c|c|c|}
\hline & \multicolumn{4}{|c|}{ TPI Index } \\
\hline & (1) & $(2)$ & (3) & (4) \\
\hline British & $\begin{array}{c}0.135^{*} \\
(0.072)\end{array}$ & $\begin{array}{c}0.099 \\
(0.074)\end{array}$ & $\begin{array}{c}0.110 \\
(0.073)\end{array}$ & $\begin{array}{c}0.174^{*} \\
(0.095)\end{array}$ \\
\hline Precol. centr. (v33) $\times$ British & $\begin{array}{l}0.058^{* * *} \\
(0.017)\end{array}$ & $\begin{array}{l}0.056^{* * *} \\
(0.018)\end{array}$ & $\begin{array}{l}0.052^{* * *} \\
(0.017)\end{array}$ & $\begin{array}{l}0.048^{* * *} \\
(0.017)\end{array}$ \\
\hline Precol. centr. $(v 33) \times$ French & $\begin{array}{c}0.022 \\
(0.015)\end{array}$ & $\begin{array}{c}0.013 \\
(0.016)\end{array}$ & $\begin{array}{c}0.013 \\
(0.017)\end{array}$ & $\begin{array}{c}0.014 \\
(0.016)\end{array}$ \\
\hline British-French Diff.: & $\begin{array}{r}0.037^{*} \\
(0.022)\end{array}$ & $\begin{array}{r}0.043^{*} \\
(0.023)\end{array}$ & $\begin{array}{r}0.039^{*} \\
(0.021)\end{array}$ & $\begin{array}{c}0.033 \\
(0.021)\end{array}$ \\
\hline Baseline covariates & no & yes & yes & yes \\
\hline Ethnic covariates & no & no & yes & yes \\
\hline Nature covariates & no & no & no & yes \\
\hline Country (2016) FEs & yes & yes & yes & yes \\
\hline Mean DV: & 0.6 & 0.6 & 0.6 & 0.6 \\
\hline Observations & 455 & 455 & 455 & 455 \\
\hline Adjusted $\mathrm{R}^{2}$ & 0.389 & 0.395 & 0.392 & 0.397 \\
\hline
\end{tabular}

Notes: OLS models. Standard errors are clustered on the ethnic group level. Significance codes: ${ }^{*} \mathrm{p}<0.1$; ${ }^{* *} \mathrm{p}<0.05 ;{ }^{* * *} \mathrm{p}<0.01$.

Table A14: Former British vs. French colonies: Recoding missing groups to zero

\begin{tabular}{|c|c|c|c|c|}
\hline & \multicolumn{4}{|c|}{ TPI Index } \\
\hline & $(1)$ & $(2)$ & (3) & $(4)$ \\
\hline British & $\begin{array}{c}-0.213^{* *} \\
(0.090)\end{array}$ & $\begin{array}{c}-0.183^{* *} \\
(0.089)\end{array}$ & $\begin{array}{c}-0.181^{* *} \\
(0.089)\end{array}$ & $\begin{array}{r}-0.138 \\
(0.095)\end{array}$ \\
\hline Precol. centr. (v33) $\times$ British & $\begin{array}{l}0.049^{* * *} \\
(0.016)\end{array}$ & $\begin{array}{l}0.032^{* *} \\
(0.016)\end{array}$ & $\begin{array}{c}0.025 \\
(0.017)\end{array}$ & $\begin{array}{c}0.029 \\
(0.018)\end{array}$ \\
\hline Precol. centr. (v33) $\times$ French & $\begin{array}{c}0.010 \\
(0.019)\end{array}$ & $\begin{array}{c}-0.001 \\
(0.019)\end{array}$ & $\begin{array}{c}-0.001 \\
(0.019)\end{array}$ & $\begin{array}{r}-0.004 \\
(0.019)\end{array}$ \\
\hline British-French Diff.: & $\begin{array}{c}0.038 \\
(0.024)\end{array}$ & $\begin{array}{c}0.033 \\
(0.024)\end{array}$ & $\begin{array}{c}0.026 \\
(0.025)\end{array}$ & $\begin{array}{c}0.033 \\
(0.026)\end{array}$ \\
\hline Baseline covariates & no & yes & yes & yes \\
\hline Ethnic covariates & no & no & yes & yes \\
\hline Nature covariates & no & no & no & yes \\
\hline Country (2016) FEs & yes & yes & yes & yes \\
\hline Mean DV: & 0.31 & 0.31 & 0.31 & 0.31 \\
\hline Observations & 893 & 893 & 893 & 890 \\
\hline Adjusted $\mathrm{R}^{2}$ & 0.117 & 0.206 & 0.205 & 0.202 \\
\hline
\end{tabular}

Notes: OLS models. Standard errors are clustered on the ethnic group level. Significance codes: ${ }^{*} \mathrm{p}<0.1$; ${ }^{* *} \mathrm{p}<0.05{ }^{* * *} \mathrm{p}<0.01$.

\section{State-level Persistence}

We use data on the constiutionalization of traditional institutions to assess the state-level persistence of policies integrating traditional institutions into their polities. The dataset codes a 


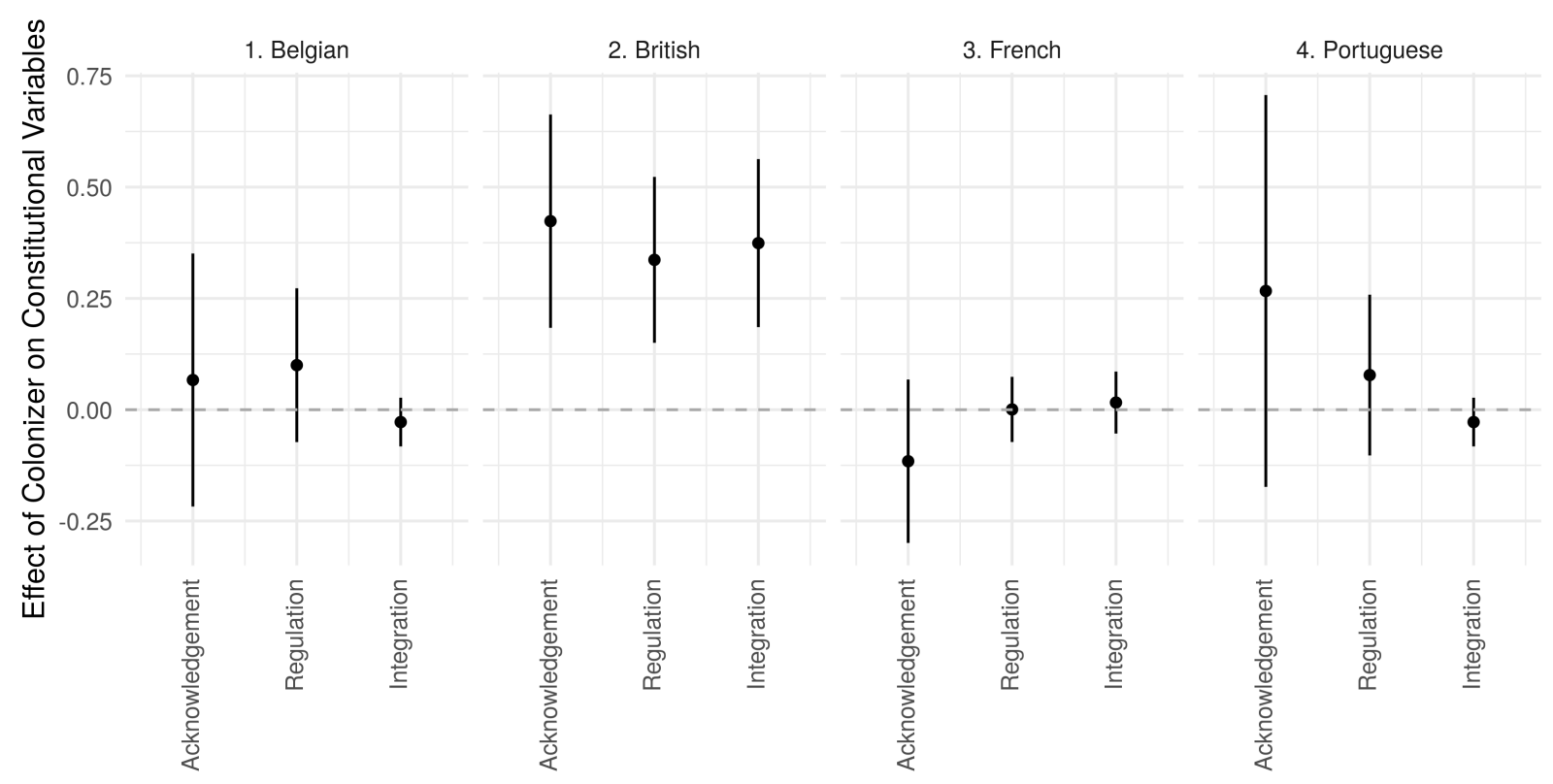

Figure A3: Correlations of colonizing power with the constitutionalization of TPIs.

Note: Coefficients with $95 \%$ CIs derived from a simple linear model without covariates where the baseline is no colonization.

cross-section of current constitutions in July 2014 for all UN-Member states (Holzinger et al. 2019).

Constitutions were coded twice by independent coders and-in case of divergent codingreconciled by a third. If official translations were not available in English, the coding was done in the original language, e.g., in Dutch, French, or Spanish. For countries with no codified constitutions, legal documents that are considered to have constitutional rank were used as the basis for coding.

From the raw dataset, we use three simple additive indices. The first index - Acknowledgment - is our main predictor and the underlying index for the two other measures. Acknowledgement codes the degree to which traditional bodies, leaders, customary law, and customary dispute resolution are acknowledged in the constitution. The second and third indices are narrower versions of acknowledgment, with different theoretical underpinnings. Regulation incorporates provisions that aim to regulate the relationship between the state and traditional institutions. These can be enabling or constraining, including official functions for traditional institutions that they can exercise in autonomy or in cooperation with the state, for instance in the judicature. Furthermore, it codes the presence of collision rules between customary law and state law, the prohibition of partisanship for traditional leaders, and the existence of official sanctions for traditional institutions. The third index - Integration - measures the degree to which traditional institutions are integrated and allowed to participate in the political apparatus of the state. For instance, some countries include houses of chiefs, as the Ntlo ya Dikgosi in Botswana that advises the parliament, or reserve seats in the state organs for traditional leaders, as in Zimbabwe, where 16 chiefs have a seat in the Senate. 


\section{E References}

Aronow, Peter M, Jonathon Baron and Lauren Pinson. 2019. “A note on dropping experimental subjects who fail a manipulation check." Political Analysis 27(4):572-589.

Birnir, Jóhanna K, Jonathan Wilkenfeld, James D Fearon, David D Laitin, Ted Robert Gurr, Dawn Brancati, Stephen M Saideman, Amy Pate and Agatha S Hultquist. 2014. "Socially Relevant Ethnic Groups, Ethnic Structure, and AMAR." Journal of Peace Research 52(1):110-115.

Cederman, Lars-Erik, Andreas Wimmer and Brian Min. 2010. “Why do ethnic groups rebel: new data and analysis." World Pol. 62:87.

Cicchetti, Domenic V and Alvan R Feinstein. 1990. “High agreement but low kappa: II. Resolving the paradoxes." Journal of clinical epidemiology 43(6):551-558.

Coppedge, Michael, John Gerring, Adam Glynn, Carl Henrik Knutsen, Staffan I Lindberg, Daniel Pemstein, Brigitte Seim, Svend-Erik Skaaning and Jan Teorell. 2020. Varieties of democracy: Measuring two centuries of political change. Cambridge University Press.

FAO. 2015. “Global Agro-Ecological Zones: Crop Suitability Index." Dataset, available online at: http://gaez.fao.org .

Fearon, James D. 2006. Ethnic Mobilisation and Ethnic Violence. Oxford University Press pp. 852868.

Feinstein, Alvan R and Domenic V Cicchetti. 1990. "High agreement but low kappa: I. The problems of two paradoxes." Journal of clinical epidemiology 43(6):543-549.

Fenske, James. 2013. “Does Land Abundance Explain African Institutions?” The Economic Journal 123(573):1363-1390.

Gething, Peter W., Thomas P. Van Boeckel, David L. Smith, Carlos A. Guerra, Anand P. Patil, Robert W. Snow and Simon I. Hay. 2011. “Modelling the global constraints of temperature on transmission of Plasmodium falciparum and P. vivax." Parasites and Vectors 4(1):92.

Goldewijk, Kees Klein, Arthur Beusen and Peter Janssen. 2010. “Long-term dynamic modeling of global population and built-up area in a spatially explicit way: HYDE 3.1." The Holocene 2010(1):1-9.

Holzinger, Katharina, Roos Haer, Axel Bayer, Daniela M Behr and Clara Neupert-Wentz. 2019. 
"The constitutionalization of indigenous group rights, traditional political institutions, and customary law." Comparative Political Studies 52(12):1775-1809.

Jedwab, Remi and Alexander Moradi. 2016. “The Permanent Effects of Transportation Revolutions in Poor Countries: Evidence from Africa." Review of Economics and Statistics 98(2):268284.

Lewis, M. Paul, ed. 2009. Ethnologue: Languages of the world. Vol. 16 SIL International Dallas, TX. Müller-Crepon, Carl, Yannick I Pengl and Nils-Christian Bormann. 2020. “Linking Ethnic Data from Africa." Journal of Peace Research, forthcoming .

Murdock, George Peter. 1959. Africa. Its Peoples and Their Culture History. McGraw-Hill.

Murdock, George Peter. 1967. Ethnographic Atlas. University of Pittsburgh Press.

Programme Against African Trypanosomosis. 1999. "Predicted areas of suitability for tsetse fly groups and species." Accessed on 2019/01/19 from: http://www.fao.org/paat/resources/atlases/tsetseand-aat/en/ .

Wooldridge, Jeffrey M. 2007. “Inverse probability weighted estimation for general missing data problems." Journal of econometrics 141(2):1281-1301. 